\title{
SOVEREIGN DEBT IN LATIN AMERICA, 1820-1913*
}

\author{
GERARDO DELLA PAOLERA \\ Universidad de San Andrés and Central European University ${ }^{a}$ \\ ALAN M. TAYLOR \\ University of California, Davis, NBER, and CEPR
}

\begin{abstract}
This paper examines sovereign lending to Latin America and the Caribbean from 1820 to 1913 . We examine four waves of capital flows where defaults were followed by a return to market access. In spite of extended default, countries kept promising high returns that attracted international investors again and again: financial autarky thus gave way to eras of high integration to global markets as measured by sovereign risk pricing. We discuss imperfections of the sovereign debt institutional context in the region and discuss a menu of options that some countries used to seek funds in the global financial markets after defaults. The parallel with the modern Latin American and Caribbean sovereign bond market experience is striking.
\end{abstract}

Keywords: Public Debt, Sovereign Risk, Sovereign Defaults, Reputation, Capital Flows, Crises, Restructurings

JEL Code: F34, H63, N16, N26, N46

\footnotetext{
* Received 24 May 2012. Accepted 20 March 2013. The authors thank the IDB for support and Leticia Arroyo Abad for excellent research assistance. Gerardo della Paolera acknowledges financial and research support during his stay at Universidad Carlos III at the Cátedra de Excelencia Banco Santander, Spring Semester 2012. The authors received valuable feedback from the editors and three anonymous referees. All errors are ours.

a Universidad de San Andrés, Vito Dumas 284, 1644 Victoria, Buenos Aires, Argentina. gdellapaolera@udesa.edu.ar

${ }^{\mathrm{b}}$ University of California, Davis, 1 Shields Ave., Davis, CA 95616, USA. amtaylor@ucdavis.edu
} 


\section{RESUMEN}

En este artículo se analizan algunos aspectos de la deuda soberana de América latina y el Caribe durante el período 1820-1913. Se examinan las cuatro oleadas del auge crediticio y del movimiento de capitales que terminaron en episodios de defaults generalizados pero que no obstaculizaron a priori sucesivos retornos al mercado de capitales en la mayoría de los casos estudiados. A pesar de defaults que se extendieron en el tiempo, los países de la región atrajeron en cada oleada a una mayor cantidad de inversores internacionales. A períodos de aislamiento del mercado de deuda soberana se le suceden otros de una alta integración con el mercado global medido por el "premio» a pagar por el riesgo soberano o riesgo país. Se discuten las imperfecciones en el mercado de la deuda soberana; los aspectos macro y microeconómicos y se discuten un menú de opciones que algunos de estos países utilizaron para reestablecer el canal de fondeo internacional luego de los defaults. El paralelismo con los vaivenes en el mercado de deuda soberana contemporánea en América latina y el Caribe resulta sorprendente.

Palabras Clave: Deuda Pública, Riesgo Soberano, Defaults Soberanos, Reputación, Flujo de Capitales, Crisis, Reestructuración

\section{INTRODUCTION}

In this paper we provide an analytic narrative that links theory and history to give an account of Latin American sovereign debt from 1820 to 1913 . We aim to relate the course of events to both empirical evidence and currently influential economic models of sovereign deft and default. Sovereign lending flows to Latin America started right after independence and were on average quantitatively large throughout the long $19^{\text {th }}$ century. But the flows were also volatile, and frequently subject to distress and default, with the borrower countries often suffering economic hardships and lack of financial market access for extended periods. Periods of exuberance with capital inflow bonanzas were often followed by retrenchments or reversals, and history reveals four such waves of capital ebbs and flows. Yet, after each crash, investors tended to return even to economies that had started to serially default.

The paper is structured as follows. Section 2 reviews the history of sovereign debt in the region for the entire period and notes the various key episodes and peculiar characteristics of the market's evolution. Section 3 brings in analytical perspectives and forges links between the observed events and the various prevailing economic theories of sovereign borrowing. Section 4 makes the link to macroeconomic conditions and long-run growth and Section 5 focuses in a more forensic fashion on certain key events that caused disruption in the market, and asks what we can learn from those cases. Section 6 concludes. 


\section{THE PUZZLING LATIN AMERICAN SOVEREIGN BOND MARKET IN HISTORY}

More than any other region, Latin America provides an expansive historical experience on the contribution to economic development of foreign capital in general, and sovereign debt in particular ${ }^{1}$. Latin America is the only part of the formerly colonial periphery with two centuries of postindependence historical experience. Once freed from Iberian rule, Latin American countries rapidly embraced the use of global capital markets to finance their public debt (and, increasingly, their private sectors too). Previously, they had made no use of such tools. It is not inevitable the colonies should be denied external financing from any source but their colonising powers - as in the British Empire debt (especially from semi-autonomous dominions) in the $19^{\text {th }}$ century, when it was held by a variety of creditors. Yet the combination of tight Iberian control and a financially immature global market in the 1700s had foreclosed this option for Latin America.

Independence opened the door to external finance starting in the 1820s. Over the next 100 years, foreign capital flows arrived in four great waves punctuated by defaults, crises, restructurings and periods of near autarky. With the outbreak of World War I, the global bond market met an abrupt end, and it would not restart for Latin American countries until the 1990s. This section reviews the historical record of Latin American sovereign debt from 1820 to 1913.

\subsection{The first wave}

In the 1820s, the new independent governments of Latin America approached the burgeoning international capital markets of London and Amsterdam, as shown in Table 1. Funding was sought to establish security and infrastructure, and on a smaller scale the private sector went in search of development finance. British investment dominated the first wave.

In 1822, government bond issues were floated by Colombia, Chile, and Peru with a face value of $£ 3.65$ million; in 1824 , there were new issues by Colombia and Peru, plus Buenos Aires, Brazil and Mexico to the tune of $£ 10.4$ million; and in 1825, Peru (yet again) plus Brazil, Mexico and Central America issued bonds for a further $£ 7.1$ million. Sold at an average discount of almost 25 per cent, these $£ 21$ million in government bonds realised on net only $£ 16$ million for the borrowers. As investors soon discovered, these issues were at best risky, at worst (in the case of the fictional Poyais) a fraud. When fiscal burdens escalated with the wars of independence and subsequent civil

${ }^{1}$ For a survey of foreign investment in the long run see Suter (1992). On Latin America, see Taylor (2005). 
TABLE 1

DEFAULT HISTORY OF LATIN AMERICAN GOVERNMENT BONDS ISSUED IN THE 1820 S

\begin{tabular}{|c|c|c|}
\hline Country & $\begin{array}{l}\text { Principal } \\
\text { owed }(f)\end{array}$ & Resolution, if any \\
\hline Brazil & $21,129,000$ & Arrears on interest paid and service resumed in 1829 \\
\hline Mexico & $6,400,000$ & $\begin{array}{l}\text { Refinancing in } 1831 \text { to cover principal and arrears on } \\
\text { interest. Quickly defaulted on. New refinancing in } \\
\text { 1837. More defaults and refunding. Resolved } 1864\end{array}$ \\
\hline Costa Rica & 13,608 & $\begin{array}{l}\text { Inherited share of Central American confederation } \\
\text { debt. Principal paid off in 1840, but not arrears } \\
\text { on interest }\end{array}$ \\
\hline Chile & $1,000,000$ & Arrears on interest paid and service resumed in 1842 \\
\hline Peru & $1,816,000$ & $\begin{array}{l}\text { Arrears on interest paid and service resumed in } 1849 . \\
\text { Default in } 1876\end{array}$ \\
\hline $\begin{array}{l}\text { Colombia (New } \\
\text { Granada) }\end{array}$ & $3,375,000$ & $\begin{array}{l}\text { Inherited } 50 \% \text { share of Gran Colombia debt. } \\
\text { Principal and arrears paid off by new loan in } 1845 \text {. } \\
\text { Default in } 1850 \text {. Principal and arrears paid off by } \\
\text { new loan in } 1861\end{array}$ \\
\hline Venezuela & $1,923,750$ & $\begin{array}{l}\text { Inherited } 28.5 \% \text { share of Gran Colombia debt. } \\
\text { Principal and arrears paid off by new loan in } 1841 . \\
\text { Default in } 1847 \text {. New arrangements and further } \\
\text { defaults then follow }\end{array}$ \\
\hline Ecuador & $1,451,259$ & $\begin{array}{l}\text { Inherited } 21.5 \% \text { share of Gran Colombia debt. } \\
\text { Principal paid off by new loan in } 1855 \text {. Arrears } \\
\text { cancelled in exchange for land warrants and } \\
\text { Peruvian bonds. Default in } 1868\end{array}$ \\
\hline Guatemala & 68,741 & $\begin{array}{l}\text { Inherited share of Central American confederation } \\
\text { debt. Principal and arrears paid off by new loan in } \\
1856\end{array}$ \\
\hline Buenos Aires & $1,000,000$ & Resumed service in 1857 \\
\hline El Salvador & 27,217 & $\begin{array}{l}\text { Inherited share of Central American confederation } \\
\text { debt. Paid off } 90 \% \text { of debt in } 1860 \text {, but balance not } \\
\text { until } 1877\end{array}$ \\
\hline Honduras & 27,217 & $\begin{array}{l}\text { Inherited share of Central American confederation } \\
\text { debt. Principal and arrears paid off by new loan in } \\
1867\end{array}$ \\
\hline Nicaragua & 27,717 & $\begin{array}{l}\text { Inherited share of Central American confederation } \\
\text { debt. Paid off } 85 \% \text { of debt face value in } 1874\end{array}$ \\
\hline
\end{tabular}

Source: Rippy (1959, pp. 26-28). 
wars, a wave of defaults ensued, with all bond issues in default by 1827 (Rippy 1959, pp. 17-24; Stone 1977, p. 692; Marichal 1989, pp. 13-14).

New loans were not extended to the region until the defaults were resolved and political and economic stability seemed more assured, a process that took years and, in some cases, decades, as noted in Table 1. Of the various 1820s sovereign issues that quickly failed, only Brazil, after a short moratorium in 1826-1829 could avoid default, but most remained in default for decades, with restructuring attempts frequently subject to failure as well (de Paiva Abreu 2006). Here was a seemingly clear case where reputation mattered: the bad debtors paid for their defaults by being excluded for a long period from the financial markets ${ }^{2}$.

\subsection{The second wave}

Starting in the 1850s, there was a marked renewal of interest in Latin America in the London capital markets. By 1880, these new investments had accumulated into a sizeable stock that dwarfed the previous boom in the 1820 s, and by then a total of $£ 179$ million was outstanding to Britain, $£ 123$ million in government bonds (69 per cent) and $£ 56$ million in private enterprise debts (Table 2). The new surge was driven in part by a global trade boom from the 1850s until the onset of the Great Depression of the 1870s. More exports and imports meant more revenues (principally from customs duties) that governments could use to amortise loans. These new debts constituted a major increase in public borrowing and a test of the governments' creditworthiness after decades of "financial hibernation». A total of fifty major foreign loans were negotiated from 1850 to 1873, most in London, and a few in Paris and other European markets (Marichal 1989).

But the extension of credit to sovereigns was more selective in the second wave as compared with the first - investors avoided the riskier locations and started to follow the signals given by the few countries that had shown some dedication to debt service. With respect to sovereign loans, Brazil had worked harder than other countries to honour debts and was duly rewarded with the largest share of the new flows. Other countries took longer to re-establish their creditworthiness. Argentina did not fully resolve internal disputes and old debts until 1857, and only then did new loans appear. Paraguay borrowed in London in 1871. Uruguay and Bolivia could do likewise in 1872 (the first Bolivian issue in 1864 had failed). Chile floated issues in 1858, 1865, 1866, 1867, 1870 and 1873 totalling $£ 8.5$ million. Costa Rica, Guatemala and Honduras all issued non-refinancing debt (new net inflows) in the peak of the investment boom from 1867 to 1872 (Rippy 1959; Marichal 1989).

\footnotetext{
${ }^{2}$ On default, punishments, and reputation, see Lindert and Morton (1989) and Tomz (2001).
} 
TABLE 2

BRITISH INVESTMENTS IN LATIN AMERICA AT THE END OF 1880

\begin{tabular}{|l|c|c|c|c|}
\hline Country & Total (£) & $\begin{array}{c}\text { Private } \\
\text { enterprise }\end{array}$ & $\begin{array}{c}\text { Government } \\
\text { bonds }\end{array}$ & $\begin{array}{c}\text { Government bonds } \\
\text { in default (year) }\end{array}$ \\
\hline Argentina & $20,338,709$ & $9,105,009$ & $11,233,700$ & - \\
Bolivia & $1,654,000$ & - & $1,654,000$ & $1,654,000(1875)$ \\
Brazil & $38,869,067$ & $15,808,905$ & $23,060,102$ & - \\
Chile & $8,466,521$ & 701,417 & $7,765,104$ & - \\
Costa Rica & $3,304,000$ & - & $3,304,000$ & $3,304,000(1874)$ \\
Cuba & $1,231,600$ & $1,231,600$ & na & na \\
Dominican Republic & 714,300 & - & 714,300 & $714,300(1872)$ \\
Ecuador & $1,959,380$ & 135,380 & $1,724,000$ & $1,824,000(1868)$ \\
Guatemala & 544,200 & - & 544,200 & $544,200(1876)$ \\
Honduras & $3,222,000$ & - & $3,222,000$ & $3,222,000(1872)$ \\
Mexico & $32,740,916$ & $9,200,116$ & $23,540,800$ & $23,540,800(1866)$ \\
Nicaragua & 206,570 & $23,540,800$ & - & - \\
Paraguay & $1,505,400$ & - & $1,505,400$ & $1,505,400(1874)$ \\
Peru & $36,177,070$ & $3,488,750$ & $32,688,320$ & $32,688,320(1876)$ \\
Uruguay & $7,644,105$ & $4,124,885$ & $3,519,220$ & - \\
Venezuela & $7,564,390$ & $1,161,590$ & $6,402,800$ & - \\
General & $10,274,660$ & $10,274,660$ & na & na \\
\hline Total & $179,490,261$ & $56,412,255$ & $123,078,006$ & $71,097,020$ \\
\hline
\end{tabular}

Source: Rippy (1959, pp. 25, 32).

As might be expected, risk premiums paid by countries varied over a wide range. Good risks like Brazil or Chile could float loans with 5 per cent coupons at a price of 80 or 90 , for a yield under 6 per cent. The exceptionalism of the Peruvian case also deserves mention. As stated by Vizcarra (2009), Peru's experience with sovereign debt was an unusual case where, in spite of ongoing political instability and a poor capital market reputation, due to the enormous guano boom, whose large export proceeds served as a quasibackstop to national solvency, the country was accorded a low credit risk until the 1870s (Vizcarra 2009). Argentine coupons ran to 6 or 7 per cent, and the issues sold at around 90. Costa Rica floated 6s and 7s and sold them for about 70. But war-torn Paraguay offered 8s, and Honduras 10s, and these bonds still could not be sold for more than 80 (Marichal 1989).

But a global macroeconomic and financial crisis was stirring yet again, and a second wave of defaults soon spread over the region in the 1870 s. By the end of 1880 of the $£ 123$ million of British capital invested in 
Latin American government bonds, more than $£ 71$ million (58 per cent) were in default (see Table 2). Some of these loans had been a bad idea in the first place, and some were again tainted by fraud. But even the genuine loans in the larger republics ran into servicing problems as the global depression spread. Credit conditions suffered. A much wider global debt crisis was under way of which Latin America was only a small part: by 1876 fifteen nonEuropean nations had defaulted to the tune of $£ 300$ million. Global capital flows again ground to a halt and irate bondholders chased down the insolvent republics long into the 1880s. Settlements were again drawn out and defaulting governments were shut out of new borrowing during negotiations and often for many years beyond.

\subsection{Third wave, crash and fourth wave}

An even bigger borrowing boom began in the 1880s as global economic activity, and especially trade, recovered. Defaulting governments gradually straightened out their fiscal problems and sought access to credit again. The overall flows were massive, and by the end of 1890 total British investments in the region were $£ 426$ million, more than double the 1880 total. Of this, $£ 194$ million sat in government bonds, now for the first time surpassed by a slightly higher amount, $£ 231$ million, in securities issued by private enterprises (Rippy 1959).

The regional distribution of the new wave of investment favoured countries that prospered the most in the new trade boom. In the 1880s, capital flows were concentrated in just five countries: 37 per cent in Argentina, 17 per cent in Mexico, 14 per cent in Brazil, 7 per cent in Chile and 5 per cent in Uruguay. Government loans were more skewed, with 60 per cent of new loans going to Argentina and Uruguay. Economic divergence was starting to be seen: Foreign capital - which sought out the most profitable investment, the most dynamic economies, and the most creditworthy countries - played a part in furthering the economic divergence in the region (Marichal 1989).

As financial development and monetisation in Latin American economies grew in the late $19^{\text {th }}$ century, the consequences of government-induced macroeconomic crises became deeper and more far-reaching. With any increase in the probability of default, sovereign spreads widened and the capital market tightened. Domestic banks found themselves in distress, and a credit crunch followed that squeezed local borrowers. Whereas government defaults in the 1820 s and 1870 s could bypass pre-modern economic modes of production that relied more on retained profits and less on financial intermediation, by the 1890s the region's more modern economies risked more resounding economic crises after a default. The major crises in the 1890s for two large capital recipients, Argentina and Brazil, illustrated these new financial risks. 
The first crisis was in Argentina - arguably the world's first example of a modern «emerging market» crisis, combining debt crisis, bank collapses, maturity and currency mismatches, and contagion. Argentina's bold development strategy of the 1880s rested on a highly leveraged parastatal banking sector, which borrowed in gold, and lent in pesos. When the economy faltered and the fiscal gap widened, it was covered by money printing, which broke the exchange rate peg and unleashed inflation. A generalised financial and banking crisis ensued. Stabilisation and debt restructuring took the better part of a decade. Foreign capital flows dried up as a consequence of the regional impact of the Baring crash, and a global recession contributed to a delayed recovery (della Paolera and Taylor 2001; Mitchener and Weidenmier 2008).

The other major crisis then hit, in Brazil. Political and economic instability was high in the 1890s following the proclamation of the Republic: the country was adjusting to the abolition of slavery, the gold standard had been abandoned, and inconsistent monetary and fiscal policies had the printing presses running at full speed. The currency steadily devalued by a factor of 3.5 from 1890 to 1898 , adding to the domestic costs of debt service. Default was put off for a time, but was unavoidable in 18981900 , and again in 1902-1909. By then, the real economy was by in deep recession, having never really recovered from the financial instability of the early 1890s (Cardoso and Dornbusch 1989; Fishlow 1989; Triner 2000; Abreu 2006).

Global capital markets quickly recovered from the crisis of the 1890s, although countries badly affected, notably Argentina, took longer to recover. However, compared with the 1870s boom and bust, this one was not associated with widespread default in the region, but rather a more general and global increase in country risk that slowed foreign capital flows for the better part of a decade. Inflows to Argentina and Uruguay were sluggish in the 1890 s, but in other countries in the region the tap was still somewhat open as shown in Table 3. As Table 3 also shows, capital flows resumed in full force from 1900 to 1914, when, as is well known, capital flows surged in the great fourth wave which represented the culminating years of the first age of globalisation, an era only brought to an end by a political shock, the outbreak of the Great War.

$$
* * *
$$

Latin America's experience was characterised by successive booms and busts, as four great waves of foreign capital flowed into the region; in the booms both private investment and sovereign lending tended to surge, but these episodes were separated by periods of near autarky in sovereign debt markets and a retrenchment in private flows. Each wave generally ended with a crisis in one or more countries. Very often it was a twin or triple crisis that damaged the value of the currency, the solvency of public debt, and 


\begin{tabular}{|c|c|c|c|c|c|c|c|c|c|c|c|c|}
\hline \multicolumn{13}{|c|}{$\begin{array}{c}\text { TABLE } 3 \\
\text { CUMULATIVE GROSS CAPITAL FLOWS FROM BRITAIN TO LATIN AMERICA, 1880-1913 }\end{array}$} \\
\hline \multirow[b]{2}{*}{ Type } & \multirow[b]{2}{*}{ Country } & \multirow[b]{2}{*}{1880} & \multirow[b]{2}{*}{$\begin{array}{c}\text { Share } \\
(\%)\end{array}$} & \multirow[b]{2}{*}{1890} & \multirow[b]{2}{*}{$\begin{array}{c}\text { Share } \\
(\%)\end{array}$} & \multirow[b]{2}{*}{1900} & \multirow[b]{2}{*}{$\begin{array}{c}\text { Share } \\
(\%)\end{array}$} & \multirow[b]{2}{*}{1913} & \multirow[b]{2}{*}{$\begin{array}{c}\text { Share } \\
(\%)\end{array}$} & \multicolumn{3}{|c|}{ Growth rates } \\
\hline & & & & & & & & & & $\begin{array}{l}1880-1890 \\
(\%)\end{array}$ & $\begin{array}{l}1890-1900 \\
(\%)\end{array}$ & $\begin{array}{l}1900-1913 \\
(\%)\end{array}$ \\
\hline \multirow[t]{8}{*}{ Private } & Argentina & 9 & 3 & 78 & 10 & 102 & 10 & 257 & 12 & 24 & 3 & 7 \\
\hline & Brazil & 10 & 3 & 29 & 4 & 40 & 4 & 90 & 4 & 11 & 3 & 6 \\
\hline & Chile & 1 & 0 & 12 & 2 & 18 & 2 & 32 & 2 & 28 & 4 & 4 \\
\hline & Cuba & 1 & 0 & 3 & 0 & 6 & 1 & 20 & 1 & 8 & 7 & 10 \\
\hline & Mexico & 4 & 1 & 19 & 2 & 27 & 2 & 64 & 3 & 17 & 4 & 7 \\
\hline & Peru & 2 & 1 & 5 & 1 & 6 & 1 & 11 & 1 & 10 & 1 & 5 \\
\hline & Uruguay & 5 & 2 & 12 & 2 & 14 & 1 & 20 & 1 & 9 & 2 & 3 \\
\hline & These 7 & 32 & 11 & 157 & 20 & 212 & 20 & 494 & 24 & 17 & 3 & 7 \\
\hline & All countries & 296 & 100 & 770 & 100 & 1,064 & 100 & 2,065 & 100 & 10 & 3 & 5 \\
\hline \multirow[t]{9}{*}{ All } & Argentina & 21 & 3 & 132 & 10 & 160 & 9 & 332 & 10 & 20 & 2 & 6 \\
\hline & Brazil & 22 & 4 & 56 & 4 & 74 & 4 & 166 & 5 & 10 & 3 & 6 \\
\hline & Chile & 8 & 1 & 22 & 2 & 33 & 2 & 60 & 2 & 11 & 4 & 5 \\
\hline & Cuba & 1 & 0 & 3 & 0 & 6 & 0 & 26 & 1 & 8 & 7 & 13 \\
\hline & Mexico & 5 & 1 & 26 & 2 & 39 & 2 & 80 & 3 & 18 & 4 & 6 \\
\hline & Peru & 27 & 4 & 30 & 2 & 30 & 2 & 37 & 1 & 1 & 0 & 2 \\
\hline & Uruguay & 7 & 1 & 20 & 1 & 23 & 1 & 30 & 1 & 11 & 2 & 2 \\
\hline & These 7 & 90 & 15 & 289 & 22 & 365 & 20 & 732 & 23 & 12 & 2 & 6 \\
\hline & All countries & 599 & 100 & 1,334 & 100 & 1,812 & 100 & 3,203 & 100 & 8 & 3 & 4 \\
\hline
\end{tabular}


FIGURE 1

BOOM AND BUST CYCLES, 1850-1914

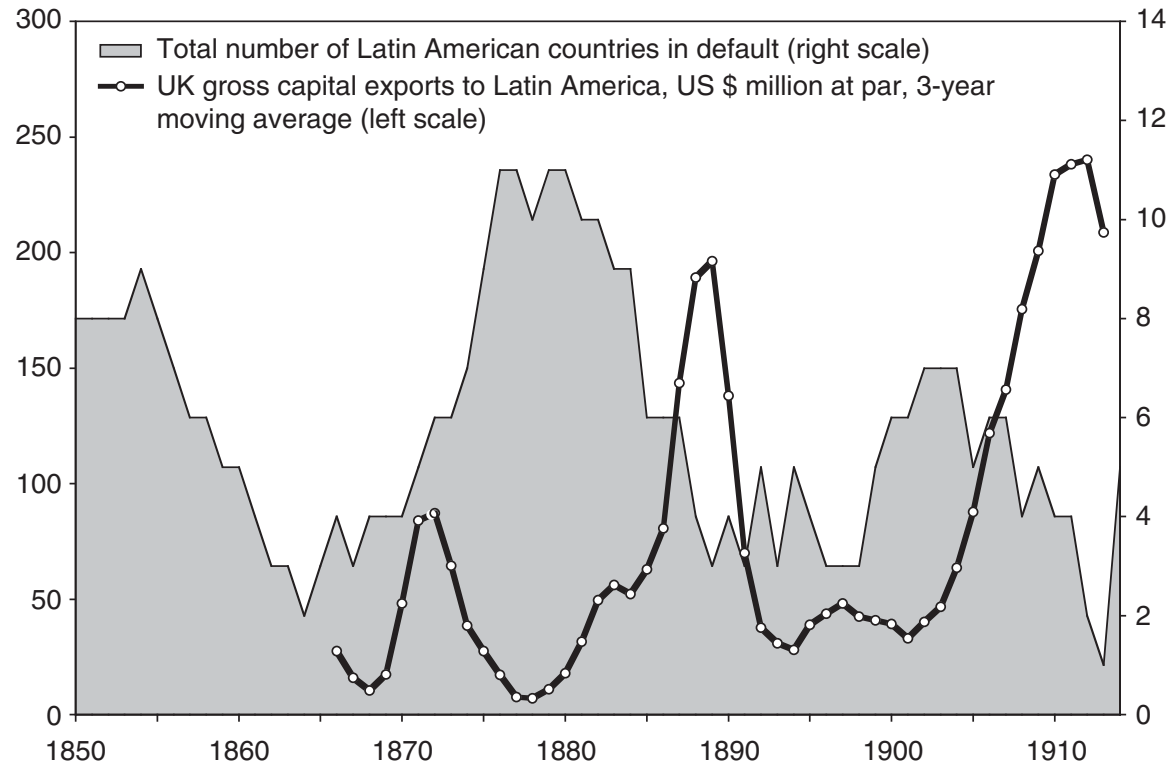

Source: Taylor (2005).

(especially in later times) the health of the financial sector. The inflows also became rather more geographically concentrated over time. Markets tended to pick out "winners» among these emerging markets, and fund them well, even after crises; other countries gained access once or twice, but spent most of their time excluded from large-scale external capital flows.

Still, the reach of the global capital market should not be overstated - the country risk perceived by foreign investors remained high and only a handful of countries had reputation enough regularly to issue external debt. Even as late as 1913, the point of deepest maturation of the global capital market before the 1980s and 1990s, the five countries of Argentina, Brazil, Chile, Mexico and Uruguay accounted for 90 per cent of outstanding Latin American issues in London. Countries like Peru and Venezuela made occasional issues, often merely rollovers of earlier defaults. Others were out of the game entirely. In the first era of globalisation, just as today, capital flows were highly volatile. To better show their stop-and-go nature Figure 1 presents annual data on capital flows to the region. If we compare trends in capital flows with the country risk data in Figure 2, for then a more complete picture of the global crises emerges. Booms were typically associated with a 
FIGURE 2

COUNTRY RISK, 1870-1914

External Bond Spread over British Consol:

Latin America versus 11 Core \& Empire Bonds

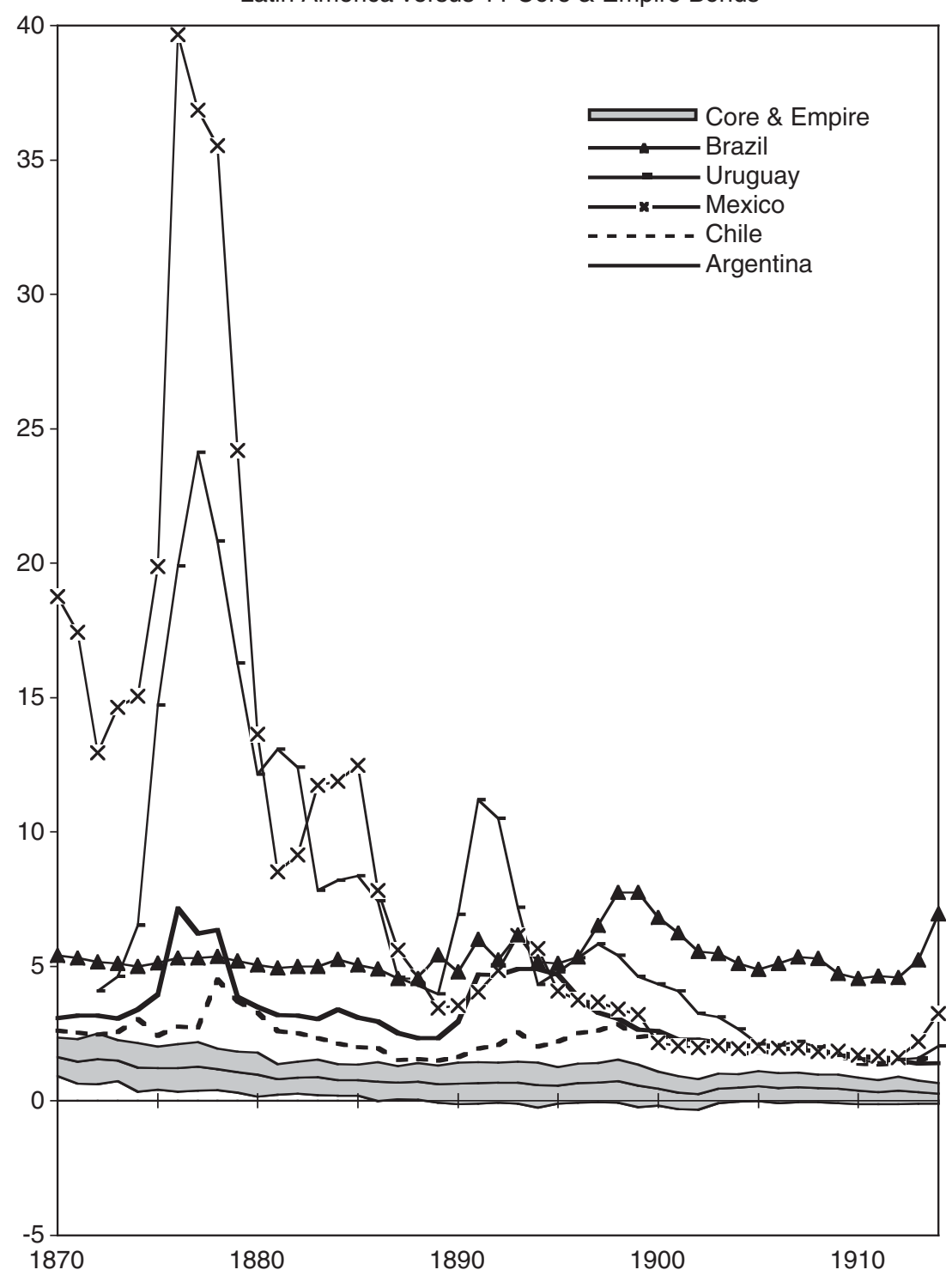

Source: Taylor (2005). 
convergence in bond spreads; defaults were associated with a sudden stop of capital flows and dramatically increased country risk.

\section{THEORY AND EVIDENCE}

We have already seen in the previous section that Latin America's sovereign borrowers experienced very heterogeneous global credit market conditions in the long $19^{\text {th }}$ century. Some countries borrowed little, some a lot. Some paid high rates of interest, some low. Some defaulted many times, others did not. The formal study of sovereign debt, using theory and empirics, seeks to explain such heterogeneity in outcomes.

The heterogeneity clearly reflected, in part, sovereign behaviour in respect of past debts. It also reflected political and economic conditions in the borrowing country. Qualitative evidence suggests that past behaviour mattered for future access. After the first wave of borrowing in the 1820s, resumption of borrowing was slow and irregular. In each subsequent wave, countries had further opportunities to improve their credit record, and those that did enjoyed access on better terms. Conversely, some countries handled their early debts so badly that they were unable to issue much debt at all later in the century. But one should also ask why did the ability to handle debt service vary so widely? What were the deep fundamentals driving this outcome? Here we might turn to the economic and political conditions in each country to try to understand what affected a country's ability and/or willingness to pay.

To disentangle competing explanations we turn to a combination of theory and empirics. Theory has often viewed the existence of sovereign debt as quite fragile, even mysterious. After all, if repayment cannot be enforced, why would any sovereign debtor repay? One obvious answer would be to secure reputational benefits in a repeated game where the punishment for default is exclusion from future borrowing (Eaton and Gersovitz 1981). Such an argument clearly depends on coordinated creditor action. One escape from that assumption is to instead assume that punishments take another form, whereby default spills over into other economic activity and cause others costs, for example, to trade (Cole and Kehoe 1996; Rose and Spiegel 2002).

However, an extraordinary result shows that this explanation may not sufficient when borrowing countries can save and build up buffer stocks of external assets. Suppose that creditors cannot seize these assets, and suppose these assets can contain contingencies similar to those of the debt contract. At some point (e.g., during a bad state of nature) a country's debt will be high enough that its future expected surpluses would be better saved and consumed rather than dissipated on debt service (Bulow and Rogoff 1989). The intuition is clear, even if the robustness of this result depends on deeper assumptions about the structure of financial markets (Kletzer and Wright 2000; Wright 2002). 
A recent contribution (Amador 2004) extends this analysis and highlights another mechanism that might be important as a sustaining mechanism for sovereign debt, one with particular resonance in the case of $19^{\text {th }}$ century Latin America. In the case of political competition, turnover among parties ensures that current incumbents may be out of power for a time, only to return in the future. In this case, they will be aware that the opposition might gain power and - being short sighted like everyone in this game - they would overspend and dissipate any buffer stock of assets. (Formally, this is analogous to a problem of hyperbolic discounting.) This threat of dissipation of any savings by the incumbent effectively blunts the incentive to employ a default-plus-saving strategy à la Bulow-Rogoff, since the assets will be spent inefficiently, and it can be shown that servicing the debt then becomes optimal. The interesting wrinkle here is that this argument only works for what Amador calls «democracy» - meaning there is some kind of turnover and current incumbents can come back after losing power (which might not mean truly democratic at all, but only that there is some political competition). In contrast, the argument breaks down under «autocracy» - meaning incumbents exit when they lose power and there is no political resurrection of parties or groups that lose power. The latter scenario could be an apt description of the violent world of mid- $19^{\text {th }}$-century Latin America ${ }^{3}$.

However, in the $19^{\text {th }}$ century, an explanation of historical outcomes requires not just an explanation for debt's existence but also for why it worked so differently in one country vs. another. Why did some countries borrow more than others? Why did some default more than others?

\subsection{Variations in investment needs}

Overall investment financed from abroad is not necessarily a good predictor of overall government spending financed from abroad. That is, the economy-wide stock or flow of foreign investment need not correlate with the subsets of flows and stocks involving the government sector. However, in the $19^{\text {th }}$ century there were powerful reasons to expect a correlation between the two and this logic underpins a discussion of the links between the two. The basic reason for the high correlation of the two measures was the strong complementarity between private and public sector investments in this period.

The case of transport and infrastructure is the obvious example. As we have noted, foreign finance of railways was a dominant category of foreign capital flows in this period (Twomey 2000). When the railroads were publicly operated, the lending was directed via government borrowing. But even

\footnotetext{
3 See Vizcarra (2009, pp. 361 and 375) on Peru during the guano boom: «During this period, Peru's foreign debt was exceptional for two reasons.... Despite Peru's ongoing political instability and poor market reputation, the price of Peruvian bonds soared shortly after settlement in 1849 ... in the case of Peru the sanction in play was not a byproduct of superior political institutions... ».
} 
when the railroads were privately owned, the construction of the railroads was often accompanied by significant public expenditure: related infrastructure, guarantees and subsidies, and so on. The same was true of ports, canals, and other large projects. At a more general level, a fast growing economy generally needed broad investments in a whole range of public goods as part of a «balanced growth» strategy, so that utilities, education, and so on, would all be higher in a high investment path.

Can simple one-sector macroeconomic models help us here? These models do not make a distinction at a fine level between types of capital, but we need to keep such complementarities in mind when understanding the motives of governments to borrow. We do know that the countries in the region had very different investment needs in the $19^{\text {th }}$ century and this certainly affected their overall need to draw on foreign capital inflows, and hence their need to engage in infrastructure-led public borrowing.

In the simplest macroeconomic sense, we could speak of some countries being much more capital scarce than others, and therefore having a much higher marginal product of capital (MPK). In a standard neoclassical model, capital would tend to flow to the countries with the highest MPK. However, in what is known as the so-called "Lucas paradox», the highest MPK need not be found in the poorest country (Lucas 1990).

Consider a standard production function where output per worker $y$ depends on productivity $A$ and capital per worker $k$. If all countries have the same productivity level $A$, then log MPK is perfectly inversely correlated with $\log k$, and classic diminishing returns means that capital will flow to the poorest country. In general, this is not true: countries do not have the same $A$ and this offers the simplest resolution of the Lucas paradox. Much of the great divergence in incomes between rich and poor countries today is explained by $A$ and not $k$ (Hall and Jones 1999; Easterly and Levine 2001). Explaining $A$ (its level and/or its growth rate) has led to debate concerning the importance of deeper determinants such as colonial history, human capital, legal origins, institutions, policies or geography (Sachs and Warner 1995; Sachs et al. 1998; Acemoglu et al. 2001; Glaeser et al. 2004).

How well do the insight from this contemporary debate translate to the $19^{\text {th }}$ century? And how well do any lessons apply to Latin America and the heterogeneous experiences within the region?

At the most general level, recent historical research suggests that the Lucas paradox was less apparent in the first era of globalisation than it is today. Figure 3 shows Obstfeld and Taylor's (2004) simple tabulation of the distribution of foreign investments by country in 1913 and in 1997. In this «then» vs. «now» comparison it is evident that the global capital markets of a century ago were much more successful at directing financial flows to very poor countries as compared with the capital markets of today. Moreover, these flows included significant investments in Latin America, for example by 1913 cumulative gross capital flows from Britain to Latin America accounted 
FIGURE 3

FOREIGN CAPITAL IN RICH AND POOR COUNTRIES: THEN VS. NOW

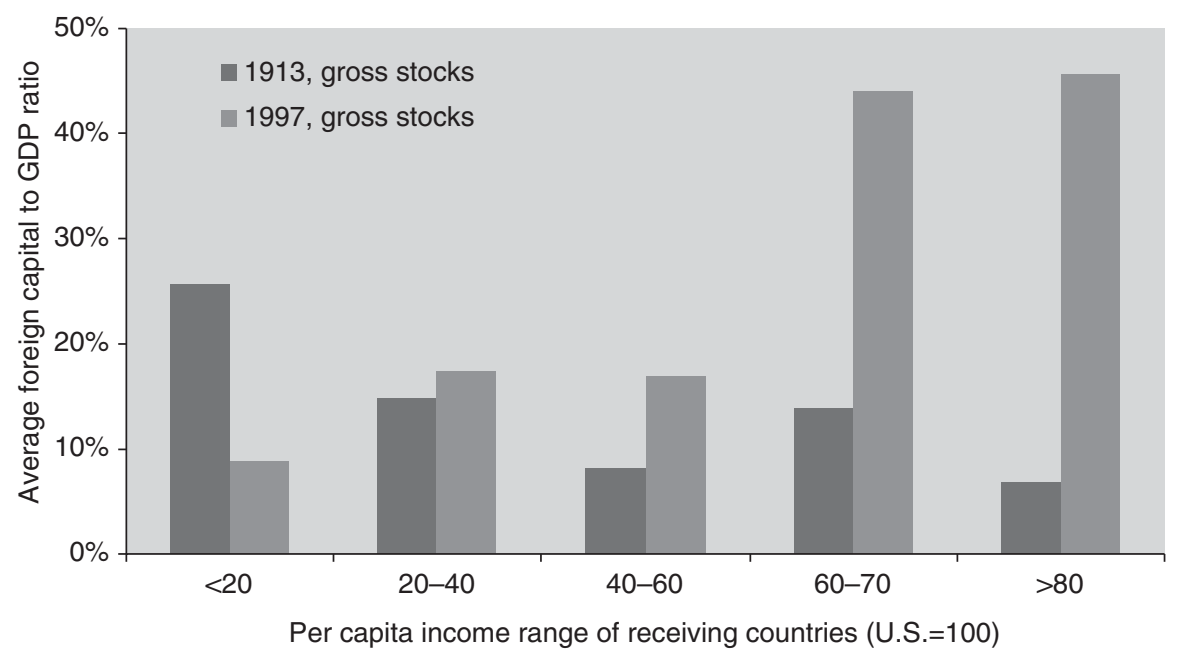

Source: Obstfeld and Taylor (2004).

for a lower bound of 23 per cent of total British overseas investments. This begs the question as to what fundamental forces led to such an outcome. To do this one may analyse the flows themselves, the quantities or the prices at which the flows moved, which in the case of government debt means looking at the risk premia charged to sovereign borrowers, a challenge we take up below.

\subsection{Variations in saving scarcity}

Since capital inflows are, by definition, the difference between domestic investment and savings, it does not suffice to look only at investment-based (demand side) determinants of capital flows, but also at the saving-based (supply side) determinants. This applies as much to aggregate flows of saving, investment and foreign capital as it does to public (government) debt. Two important aspects of the Latin American economies on the supply side should be noted, factors that have persisted to some extent up to today: financial underdevelopment and demography.

According to financial historians like Davis (1965), the function of capital markets in the aggregate can be broken down into two functions: the mobilisation of savings supply resources and the allocation of these resources to competing investment demands. If the system is efficient, then the 
maximal resources are mobilised, and they are allocated efficiently across sectors and firms ${ }^{4}$. This ideal is never reached, and reality falls particularly short in developing countries.

In a closed-economy view of the world, these failures of financial development could place a serious brake on economic growth. (Schumpeter 1911; Gurley and Shaw 1955; King and Levine 1993). Some evidence has been adduced to this effect, although controversy still swirls around the finance-development nexus given the possible reverse causality running from growth to finance.

In an open economy world, however, the inefficiency of financial markets may place a tax on long-run national wealth, but it need not slow economic growth. In a hypothetical frictionless world, small open economies lacking the means to mobilise or allocate their own savings could still draw on the pool of global savings available at the real world interest rate. Foreign banks and financial firms might then enter the domestic market to allocate and monitor the capital so raised. In line with this logic, in the $19^{\text {th }}$ century, differences in domestic financial development did not necessarily hinder countries' ability to accumulate capital, even if they did affect subsequent development paths once the global capital market collapses ${ }^{5}$.

For government finance, the effect was to supply at low transaction costs a large group of counterparties in London, and elsewhere, who were willing to subscribe to government debt issues, for whom the investments in any one periphery country were a small part of their portfolio. In contrast, working through the domestic financial market meant high transaction costs using inefficient banks to reach a small pool of domestic investors for whom a debt issue would be a large share of their portfolio. It is easy to understand why the former route would be preferable. Indeed, the latter route was often ignored, unless there were telling reasons to use it - for example, a loss of access to external credit after a default, or a desire to engage in financial repression or "forced savings» and thus tax the domestic bond holders (whether institutions or individuals) either through below market nominal interest rates or via the inflation tax on paper debt, tactics that could not be exploited too often without totally destroying what little financial development there was.

${ }^{4}$ See, however, Flandreau and Flores (2009) on «bonds and brands»; more on this topic later in this paper.

5 For example, Davis and Gallman (2001) find that in the «settler economies» the British Dominions generally had more advanced financial systems than Argentina, a finding consistent with the account of della Paolera and Taylor (2001). In the Argentine case, penetration by foreign banks, many of them branches of London banks, brought the country to the doorstep of the deep and liquid British financial markets. In this type of setting, foreign financial development can substitute for and thus crowd out - domestic financial development. See also Regalsky (2002) on the influence of French Banks during the third and fourth waves. This effect was probably at work in many less developed economies, within and beyond the British Empire, before 1914. 
In essence then, open capital markets created the possibility of «trade diversion» in asset trade. We can recast this in the language of gravity models, which have been successfully applied to financial flows also. In a country with poorly developed capital markets the intra-national transaction costs were high. If the country were closed, however, «multilateral resistance» against all foreign countries would be high, sustaining the domestic market. But if inter-national transaction costs suddenly fell — globalisation - the country would be expected to divert financial flows from domestic to foreign markets.

These forces were something of a double-edged sword in countries that plugged into the global capital market before 1914. On the plus side they made the supply of capital much more elastic, and this could help explain the very positive association between foreign investment and growth, notwithstanding any claim about causality (Schularick and Steger 2006). On the minus side, these pressures possibly deterred domestic financial development. The latter proved to be a major weakness once global capital supply dried up after 1914. Countries had to turn to the domestic supply of capital, and domestic intermediaries. As argued, the intermediaries were often few and inefficient ${ }^{6}$. In addition, supply of capital was low too. Why?

The dominant explanation argues not only that savers were cutoff from investors by high transaction costs, but that savers were themselves rather scarce for demographic reasons. Taylor (1992) made the argument for Argentina, and it would apply to some other countries too. In many developing countries then, as now, fertility and population growth rates were very high. The standard life cycle argument would predict that such countries would tend to save less, as compared with countries with a more mature population with greater numbers in high-saving mid-life cohorts. Taylor and Williamson (1994) show how these effects could explain a fair portion of the capital flows from Britain to the settler economies before 1914.

This argument offers another explanation for the need for governments to borrow from abroad - at home, there were few savers in the population. This may well have been efficient for other reasons. Much domestic saving in Latin America was within the firm or the household, and this was probably important for the financing of many small firms and businesses. We know, for example, that domestic stock markets were often quite thin and banks were often financing only large firms with some type of «connection» (Haber 1991; Triner 2000; Regalsky 2002; Hanley 2005). Thus, small enterprises, if they relied on domestic saving were liable to feel crowding out if government borrowing went directly to bond issues to the domestic market, simply because such small firms were likely to have severe asymmetric information problems that would preclude them issuing debt or equity abroad. On the other hand, the government was rather better placed to issue debt overseas as compared

${ }^{6}$ Flandreau and Flores (2009) discuss inefficiency in the 1820s/1830s era. The problem may have abated, but not entirely disappeared, in subsequent decades. 
with such small firms, so it did them a favour by doing so, leaving most of the market and non-market domestic capital flows untouched.

So far we have examined government (and aggregate) borrowing as driven by the forces of demand and supply. However, a third and final set of factors must be considered - frictions or wedges, in the form of transaction costs. These costs raise the expected return of the marginal dollar invested above the expected returns of the marginal dollar saved, and thus serve to inhibit transactions between borrowers and lenders.

For $19^{\text {th }}$ century Latin American governments borrowing in the world capital market, these frictions took two principal forms: exclusion from the market, leading to quantity rationing; or market access subject to a risk premium, a sovereign spread over the market's benchmark bond yield (in those days the British consol). Market exclusion, as we have seen, was typically a result of unresolved past defaults. What drove risk premia? A considerable body of research in recent years has explored this topic, and several pertinent findings can be summarised ${ }^{7}$.

\subsection{Gold standard}

In a seminal paper, Bordo and Rockoff (1996) offered evidence that sovereign borrowers received a lower risk premium when they adhered to the gold standard - the authors referred to this as a «seal of approval» whereby the sound policies necessary to achieve successful (i.e., credible) commitment to the gold standard also operated to lower the macroeconomic risks that were of concern to holders of sovereign debt, namely the risks of default because of economic underperformance or fiscal crisis. This hypothesis was lent further support by Obstfeld and Taylor (2003) who studied much larger sample of countries in the 1870-1913 period. The risk premium appeared to be 40 or more basis points lower for a country after it went on gold, and this effect remained after many other controls were added.

Of course, being on the gold standard was an endogenous outcome and was also correlated with many other macroeconomic variables, so this effect needs to be carefully interpreted. More generally, attempts to extend the Bordo-Rockoff analysis by adding right-hand side variables to produce a «kitchen sink» regression have to be interpreted with care, and if the righthand side variables are collinear with the gold standard then the results may be meaningless.

To illustrate the correlation problem, we can examine results in Flandreau and Zumer (2004) where exchange rate volatility is added to most regressions

${ }^{7}$ For a comprehensive of this topic, the reader is referred to Mauro et al. (2006). See also on spreads and institutions Accominotti et al. (2011). 
and the authors find that the inclusion of this variable reduces or negates the impact of gold standard adherence. This is not surprising since going on gold was the way in which countries lowered their exchange rate volatility in this period: hence these results, which ignore the fact that exchange rate volatility depends on the exchange rate regime, offer no evidence for or against the «seal of approval» hypothesis. A more robust attack on the gold standard effect was offered by Ferguson and Schularick $(2006,2012)$ : they have a larger sample that includes many African and Asian poor countries. In poorer countries (where the cutoff was in the US $\$ 1,000-2,000$ per capita range in 1900, roughly $20-40$ per cent of the British level), the impact of the gold standard on spreads appears weak: perhaps their politico-economic institutions were too weak to make gold standard commitments credible. However, in samples that focus more on the rich Atlantic economies, and include the main Latin American borrowers the gold standard effect remains. We might infer that, as a region of middling incomes and middling institutional quality, Latin America was poised on the periphery of an Atlantic club where gold standard adherence could, if credible, offer some benefits.

Even if that is accepted, however, the endogeneity of the gold standard is a more difficult nut to crack. Econometrically, Obstfeld and Taylor (2003) used GMM techniques to address this issue, but other approaches still need to be explored, for example the use of a first-stage model of gold standard adoption along the lines proposed in an innovative paper by Meissner (2005). These results matter for the Latin American countries in the $19^{\text {th }}$ century because they were generally among the weakest of countries at maintaining gold standard adherence. However, returning to the endogeneity issue, this really begs the question: why? What was it about the region's economies that made it so difficult for them to stick to a hard monetary regime?

\subsection{War}

Obstfeld and Taylor (2003) also included controls for the occurrence of military conflict involving the sovereign borrower, both civil war and interstate war. Perhaps surprisingly, both of these variables turned out to be statistically insignificant as determinants of country risk. Ferguson and Schularick (2006) found mixed results. However, the arguments of Bordo and Kydland (1995) that the gold standard was a «contingent rule» caution against a simple interpretation of these weak findings. Wars tended to mean going off gold, so indirectly, via the gold standard effect, we may still be capturing an effect of conflict on sovereign risk. Returning to the last point, we can see here one endogenous source of weak gold standard adherence. In this sense, we do find support for the notion that the prevalence of conflict in the region may have had something to do with Latin America's high sovereign risk. Again, this cautions against using the kitchen sink regression as a means to refute the gold standard as a seal of approval. 


\subsection{Institutions and empire}

Looking at institutional determinants, it is not clear that most parts of Latin America could have been expected to attract large-scale capital flows. Stressing extractive institutions arising from colonial origins, Acemoglu et al. (2001) reach a conclusion that builds on the insights of North and Thomas (1973) concerning the legacy of Iberian rule in Latin America. Spain and Portugal did not establish colonies that were characterised by good political and economic institutions. Power was concentrated in privileged elites, democracy never flourished, property rights and rule of law were weak (except where needed to protect the elite). In the AJR account these flaws persisted after independence, and slowed economic growth, keeping the region poor. Here, institutions are the fundamental driver of $A$, which in a Solovian model determines a country's level of productivity and hence income per capita in the long run as $k$ converges to a steady state level that depends itself on $A$.

The Acemoglu et al. view is often - wrongly — seen as purely deterministic, but of course there is still an error term in their model, and residual variation is significant. Between the colonial past and present outcomes, history reveals even bigger residual variance. In a challenge to the persistence story Prados de la Escosura (2005) notes that the "great divergence» between Latin America and the core economies was even more a $20^{\text {th }}$ century than a $19^{\text {th }}$ century phenomenon. If Prados de la Escosura is correct, then, perhaps despite political and institutional weaknesses, the region did manage to sustain growth in the $19^{\text {th }}$ century, and hence became attractive to foreign capital, except where the worst political and institutional failures could not be contained.

This may call for future research to assess the more detailed mechanisms needed for an «institutional explanation» - that is, why some institutions matter more than others, and at some times more than others. For example, Vizcarra (2009) explains clearly that the vast amount of exportable resources (the guano) and a well-structured debt service scheme could overcome the complete lack of Peruvian stable political institutions. Some countries obviously surmounted their colonial legacies, if only for a time, and were able to get onto a reasonably fast growth track. The most dramatic example would be Argentina, which by 1900-1913 was one of the five richest countries in the world and a prime destination for foreign capital. Argentina's subsequent growth failures put the country back in the ranks of the less developed a century later, so perhaps its colonial legacy finally caught up with it. Brazil, and several other countries have also witnessed ups and down in growth performance, yet without sustained convergence. These perturbations along the development path deserve greater scrutiny, as we need to better understand the extent to which countries are "prisoners of history» and how many degrees of freedom they have that allow them to escape from their past. 
In this respect Latin America again stands as a crucial test case. In other areas of the periphery still under colonial rule, it would be simple to attribute the large flows of capital in the 1870-1913 period to institutions, such as rule of law and property rights that were enforced by the colonial powers themselves. As Lucas himself noted:

Until around 1945, much of the Third World was subject to Europeanimposed legal and economic arrangements, and had been so for decades or even centuries. A European lending to a borrower in India or the Dutch East Indies could expect his contract to be enforced with exactly the same effectiveness and by exactly the same means as a contract with domestic borrowers. (Lucas 1990, pp. 94-95)

The same idea supports the theory of «anglobalization» that underpins Ferguson's (2003) qualified rehabilitation of the benefits of the British Empire. Of course, empires have since collapsed and it can be argued that this crucial difference explains the absence of a Lucas paradox then, but its presence today (Schularick and Steger 2006).

Whether one views the financial and institutional exports of the European imperial epoch as a plus or a minus, it is fair to say that Latin America's postindependence experience remains relatively neglected in this explanatory framework, and fits none to well either with the pro- or anti-colonial view. The region was politically independent then, as now; and some countries enjoyed respectable economic growth and capital market access; we still have to answer how they pulled it off. On the one hand, defaults were undoubtedly higher "on average» than in the Empire group. On the other hand, the region still managed to attract significant capital flows despite those risks. The benefits (returns) must have outweighed the costs (risks), which would be consistent with the Prados de la Escosura (2005) story that, despite its flaws, some parts of the region had good growth potential. Colonial origins did not doom the region to failure, at least up to 1914 .

The empire thesis was examined by Obstfeld and Taylor (2003) and Ferguson and Schularick $(2006,2012)$. Both found little evidence for an «average» discount based on British empire membership using the industrystandard (Bordo-Rockoff 1996) CAPM framework, but the latter found stronger support for a lower «beta» among Empire borrowers when an Empire-beta interaction was added. Ferguson and Schularick (2006, 2012) have the advantage of an even bigger sample than Obstfeld and Taylor (2003), including many more British colonies in Asia and Africa, although such a sample obviously weights Latin American observations a lot less. Both also found evidence of noticeable convergence of risk premia over the 18701914 period. In the Ferguson-Schularick framework, this trend is mopped up either by time dummies or by the CAPM Empire-beta interaction, and in both cases it negates the gold standard effect: in the former case «something 
else» explains convergence and in the latter case it is the gradual diminishing amplitude of the global weighted risk premium. Of course, either or both of these effects are correlated with the global spread of the gold standard, so inference is still unclear. We need to remember that the gold standard was not viewed as a fundamental by Bordo et al.: merely as a "seal of approval» which, if credible, was indicative of other fundamentals. Such fundamentals could, of course, include the Empire - where the gold standard was virtually a sine qua non of macroeconomic regime design.

Could such an alternative explanation exist for interest rate convergence after 1870? Perhaps «institutional convergence» was afoot in the global economy in this period? Schularick and Steger (2006) argue that smaller property rights differentials could explain the absence of a Lucas paradox before 1914. However, with no data on property rights before 1914, this hypothesis awaits further testing, for example, in the manner of Alfaro et al. (2005). But why would such a convergence have occurred? And when? One might appeal to the notion of «informal empire» or «soft power» to argue that, in effect, British (or at the least, European) capitalistic norms were being spread around the globe under the influence of the colonial police powers - that «anglobalization» had spillovers beyond the formal empire itself by setting global «rules of the game» in the shape of norms for good behaviour, that is, global public goods (Ferguson and Schularick 2006, 2012). Such an argument would say that, for all its notional independence, Latin America could not have chosen to abrogate property rights before 1914 without facing deep shame and (more importantly) stiff penalties. There is some evidence that the flexing of U.S. power in the Latin American region may have been instrumental in this regard (Mitchener and Weidenmier 2005). However, with no way to measure informal empire or its influence, these conjectures remain largely untestable. Indeed, if the entire globe is under the sway of an informal empire, the hypothesised effect cannot be identified at all.

\subsection{Default history}

Another place to look for an explanation of high sovereign risk is in the default record. Obstfeld and Taylor (2003) found a high penalty for contemporaneous default: maybe 100 basis points for full default and 50 basis points for partial default. But what about the longer term record? Ferguson and Schularick $(2006,2012)$ also find a strong impact of past default on current spreads.

The role of past default in determining current spreads is central to the «reputation» model of the sovereign debt market. The 1820s and 1870s crises started to cement in investors' minds the untrustworthiness of Latin American sovereign borrowers, a reputation that was to expand in the years ahead and which persists even to this day. According to Tomz (2001), of the 
FIGURE 4

DEFAULT, 1825-1940

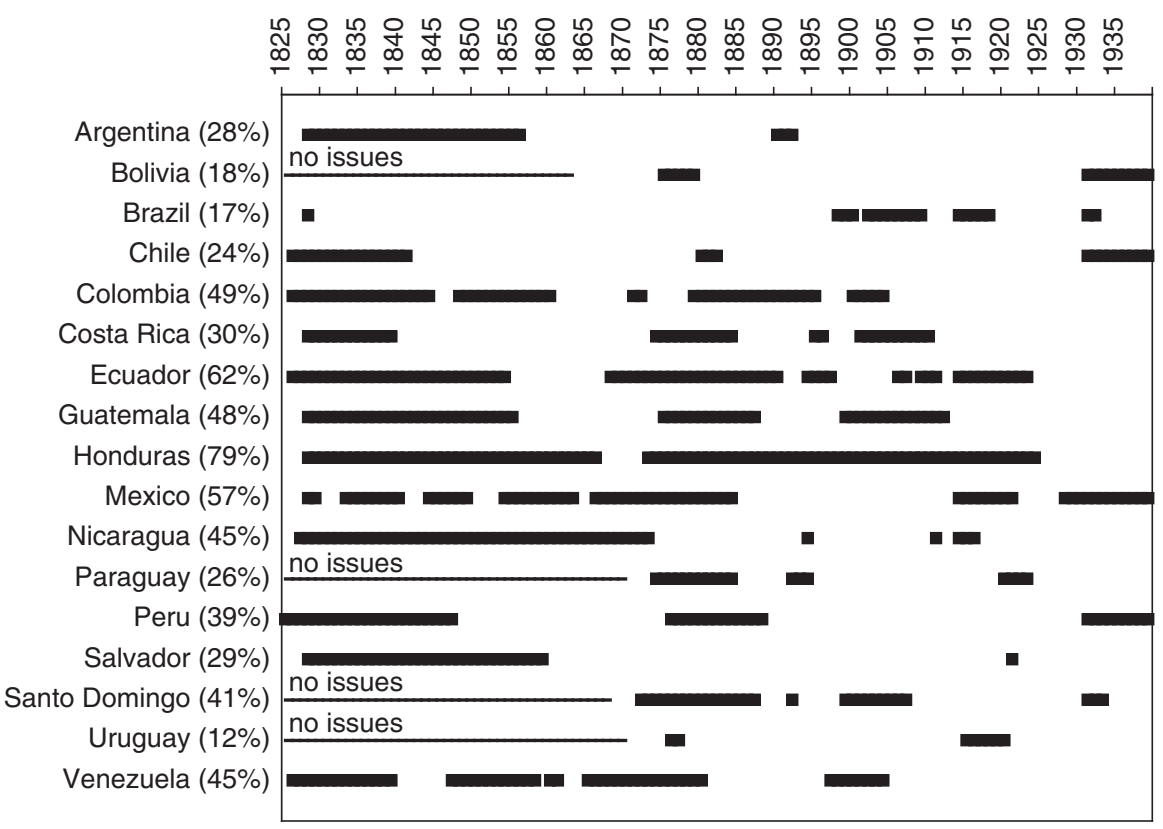

Note: Fraction of years in default shown in parentheses.

Source: Taylor (2005). Default data from Tomz (2001), issue dates from Marichal (1989).

seventy-seven government defaults from 1820 to 1914, fifty-eight involved Latin American countries (75 per cent). Compared with other periphery countries, the economic potential and sovereign independence of the region obviously encouraged this outcome: the potential for high returns encouraged more borrowing ex ante and the independence from Empire gave more freedom to default ex post.

Clearly the borrowers in the region could not manage their fiscal affairs with anything approaching the prudence of most borrowers in the core countries. Figure 4 shows the incidence of sovereign default in the region from 1820 to 1940 and the fraction of years that debtors spent in default status is impressive, 38 per cent on average. The better-behaved borrowers like Uruguay (12 per cent) or Brazil (17 per cent) managed to maintain a pretty clean sheet, but the odds of getting repayment from others like Honduras (79 per cent) or Mexico (57 per cent) were no more favourable than a coin toss.

We can assess the importance of reputation for capital market access in the first era of globalisation by following Reinhart et al. (2003, «RRS») and 
Reinhart and Rogoff $(2004,2009$ «RR»). We look at the relationship between default history and country risk. The country's default history is captured by the number of defaults or the fraction of years spent in default over a specified prior period, in this case 1801-1900. Country risk is measured by the spread of the country's long-term gold bond yield over the benchmark yield of the British consol, using data collected by Obstfeld and Taylor (2003), in this case for 1900-1913.

We might expect that a country with a record of «serial default» ought to be penalised with higher country risk, and «RRS» show that this is the case in the present era. "RR» show that this behaviour matters for capital market access today. Was it true in the past also? Figure 5 shows that more defaults and longer defaults in the $19^{\text {th }}$ century were associated with higher spreads in 1900-1913. In other words, the problem of serial default is an old one, and there appears to be evidence that even in the $19^{\text {th }}$ century, global capital markets were quick to identify and punish a serial defaulter.

\subsection{Fiscal burdens: levels and volatility}

Obstfeld and Taylor (2004) found that debt/GDP ratios had very little impact on sovereign risk in the 1870-1914 period, suggesting that so long as the debt path was consistent with gold standard adherence, creditors were willing to take the latter signal as credible and allow quite wide movements in public debt to GDP ratios, a pattern that was to change dramatically in the interwar period. Nonetheless, alternative models of risk premia in the 1870-1914 period have given different results: Flandreau and Zumer (2004) and Ferguson and Schularick $(2006,2012)$ found evidence that debt/revenue ratios did matter for sovereign risk, and that in some specifications these debt burden measures could sometimes lessen the impact of gold standard adherence. Empirically, the question is likely to remain unresolved until we can better model the endogeneity of debt levels, which were surely correlated with the ability to make a credible gold standard commitment. But in theory the result is clear: unsustainable debt paths will usually break any commitment to gold, since they are almost surely indicative of fiscal weaknesses that will, at least in some states of nature, cause explosive budget dynamics. It is quite possible that the gold standard seal would not be apparent once such a control was added.

However, debt levels are not the only matter of concern for creditors. The volatility of the fiscal situation is also important. The unusual volatility of public debt in the region is shown in Table 4. More than the core or the periphery as a whole, the Latin American economies seem to have been more susceptible than any other group of countries to extreme fluctuations in public debt to GDP ratios. The region's governments experienced big run ups in debt levels during periods of easy credit, followed by big crashes during 
FIGURE 5

SERIAL DEFAULT AND COUNTRY RISK

(a)

Histogram

Average Spread of Long Term Gold Bond over

basis points the British Consol Yield 1900-13

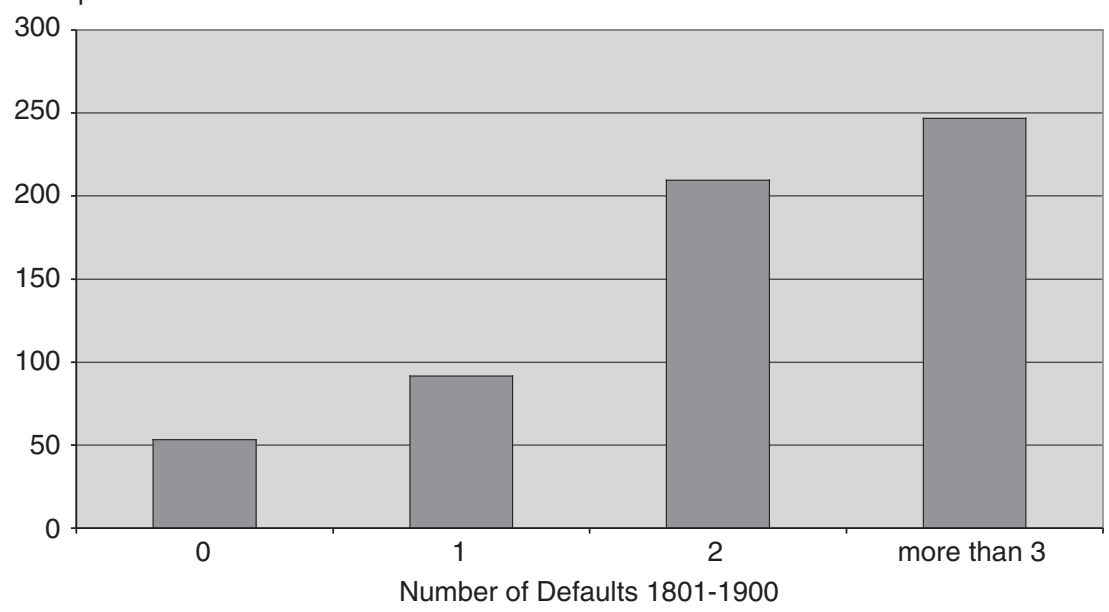

(b)

Scatterplot

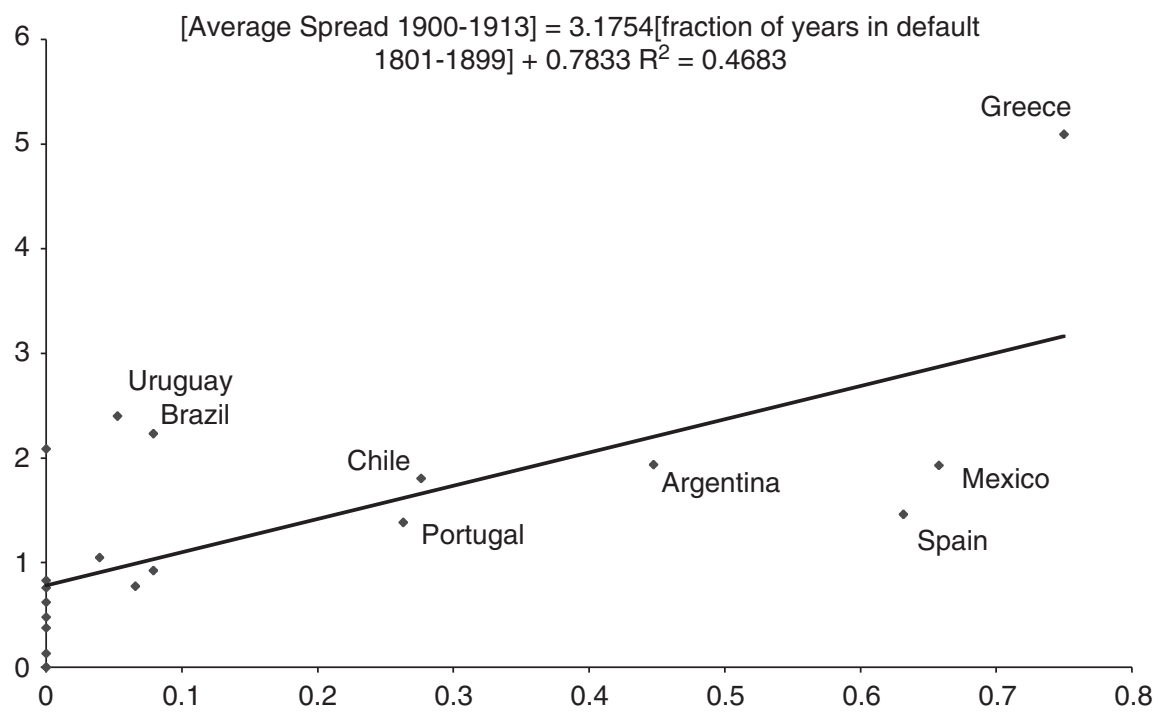

Source: Obstfeld and Taylor (2004), Reinhart and Rogoff (2004). 
TABLE 4

VOLATILITY OF PUBLIC DEBT TO GDP RATIO, 1870-1913

\begin{tabular}{|l|c|c|c|c|c|}
\hline Sample & $\boldsymbol{n}$ & Mean & SD & Minimum & Maximum \\
\hline Latin America & 149 & 1.31 & 0.91 & 0.29 & 3.39 \\
Periphery & 439 & 0.99 & 0.77 & 0.11 & 3.54 \\
Core & 391 & 0.46 & 0.39 & 0.01 & 1.42 \\
\hline
\end{tabular}

Source: Obstfeld and Taylor (2004).

tighter times or after a default/repudiation episode. This led to higher means and standard deviations of public debt to GDP ratios as compared with other countries, especially core countries and even other periphery countries. In an institutionally sound and financially mature environment, such data might reflect the decisions of a strong optimising government taking maximal advantage of the flexibility provided by a debt-financed buffer. But in a financially and fiscally backward periphery environment these data tell a different story - a tale of fiscal "snakes and ladders» where governments were poorly equipped to cope with tax and spending shocks, forced to use debt (when not using the printing press), and eventually crashing into debt ceilings, followed by default, and austerity.

One might view these higher moments of the fiscal deficit as exogenous "fundamentals» linked to political and institutional weakness. In this view, Latin American countries were burdened with fiscal volatility either because their tax revenues were volatile (e.g., due to trade volatility and terms of trade shocks affecting customs revenue) or because spending was volatile (e.g., due to wars and military spending caused by internal/external political instability). Alternatively, shocks may have been no different but the governments' propensity to use external borrowing may have simply been higher. The latter might reflect institutional weakness of a different sort, namely the suboptimally short time horizons of sovereigns. Whatever the origin, it is clear that Latin America governments lived in a more fiscally volatile world and witnessed more dramatic fluctuations in their debt positions than other countries in the core or periphery.

\subsection{Access to capital markets: the microeconomic explanation}

A recent, novel, and compelling explanation addresses the issue of how sovereign debt emerges, subsides and then again re-emerges, as advanced by Flandreau and Flores (2009). The central problem they analyse is a scenario where there are severe information asymmetries, where countries renege on their contractual arrangements, and where financial intermediaries have incentives either to make debt sustainable against all macroeoconomic odds or to cheat investors. In their explanation it is the reputation or «brand» of 
the financial intermediary or underwriter which is the key mechanism that helps overcome the enormous information asymmetries and market imperfections. This approach addresses two related stylised facts to solve the sovereign debt puzzle: (1) the existence in general of overshooting in lending and (2) the heterogeneous performance of countries seen during each of the capital flow waves.

Their study differentiates between wildcat underwriters and top-rank well-reputed ones; evidence suggests that more reputable banks with a longer time horizon supported borrowers with the intention to help maintain their access to capital markets. In contrast, wildcat underwriters would engage in selling the bonds with a short horizon. They observe that many sovereign defaults followed and yet did not precede intermediaries' failures. According to this market structure analysis the underwriting business was a hierarchy - not a competitive perfect market. And the champions of all were the Rothschilds who always signalled the best of the best investment-grade securities. A contrast is the Barings house that was involved with issuers of much more risky bonds, as became clear. When the Rothschilds acted as underwriters of Brazil, for example, they put at stake their own reputation but also this acted as a transfer of information about the fundamentals of the country via the underwriter. In this view, even if investors could not learn directly very much about borrowers and their fundamentals, they could learn more easily about underwriters, the more reputable of which could then give a bond issue a «seal of approval». The hierarchy of underwriters was thus a proxy for the hierarchy of users. On the other hand, the fact that prominent houses did act as agents, but not as underwriters, could have signaled «risky bets» and hence might have fed sizeable periods of overborrowing.

\section{SOVEREIGN PUBLIC DEBT AND THE MACROECONOMIC HISTORY OF LATIN AMERICA}

Access to foreign savings to finance either public or/and private enterprises was a permanent characteristic that has conditioned the economic development of the region. The external or sovereign public debt played a «multipurpose» function in the region's development and sheds an important light on the dynamic linkages between public finances and developmental and infrastructural needs of these newly independent nations.

We argue that key aspects of the sovereign debt - its size, availability and, most importantly its strategic management - cannot be understood solely in terms of a simple closed economy macroeconomic model which might be suited to study the nature and evolution of debt in countries such as Britain, France, Germany, and even the idiosyncratic case of the newly settled United States. In these countries that successfully developed internal capital markets, tax smoothing and the presence of «abnormal» spikes in the 
level of the internal public debt (relative to GDP) are basically a by-product of recessions in the former case and the finance of war efforts in the latter case (Barro 1989) ${ }^{8}$. But, in general, these countries, during the modern era, could finance their public budget imbalances by resorting to the issuance of internal public debt denominated in their domestic currency or by engineering changes in tax policies. The effectiveness of such tax policies depended on a diversified tax base, something lacking in the fiscally fragile nations of Latin America. In Latin America, the conduct and management of public finances crucially determined how these independent countries coped with turbulence and illiquidity in international capital markets, particularly when a net transfer of resources to the capital markets in the central countries had to be effected.

Public debt, and especially sovereign public debt, was also linked to: (a) the finance of the immense economic opportunities present in Latin America in which the new nation states were stakeholders; (b) the building of new infrastructure to channel the production of goods or extraction of natural resources to the developed world; (c) the support of sound monetary and banking regimes in light of accepted international standards; and (d) the guarantee of a minimum rate of return to certain private equity ventures, to hedge some of the risk of inward foreign direct investment. Obviously, the private inflow of capital for direct investment and for trade financing is a topic of utmost importance for developmental issues in Latin America and it has been very well documented by Feis (1931) and Davis and Huttenback (1988) for the British Empire. In this study we examine the experience and strategic issues concerning the issuance of sovereign public debt in Latin America countries. In our discussion, we do not explicitly include the financing of the independence wars of Latin America, because the experience is very heterogeneous in the different nations of the region, as many have noted.

As is evident today, where we witness similar levels of integration in international bonds markets, turbulence is to be expected. According to Harold Peters, a respected scholar of the Argentine debt:

The Latin-American republics have always been burdened with debt, perhaps as a necessary condition of independence.... The flow of capital from Great Britain, and later from the continent and the United States to debtor countries, has been an intermittent one. Waves of intense optimism, during which almost any properly engraved certificate, could be sold at a high price, have alternated with troughs of

${ }^{8}$ Although as Ferguson (2001, p. 142) points out correctly: «Although the American Federal Government never defaulted on its debt, the same cannot be said of the American States themselves. In the recession of 1837-43, there were defaults on around half of the outstanding state debt; 10 per cent of the total amount owed by the states was repudiated altogether. There were further rashes of default in 1857 and again in the 1870s. Latin American States were the perennial defaulters of the nineteenth and twentieth centuries». 
profound pessimism, in which the export of capital stopped completely. There is one thing for which a subscriber to an issue of foreign bonds by an undeveloped country must be prepared - an interval of default. (Peters 1934, p. 1)

The statement resonates with many of the most modern theoretical developments about the sustainability of the dynamics of the public debt for an underdeveloped country: the dependence on the world economic cycle in terms of the evolution of international interest rates and the evolution of the terms of trade for a particular indebted country and the phenomenon of «sudden stops» (and also "sudden gos») to use the terminology of Calvo (1998). The extent of booms and busts of export of capital to Latin America shown in Section 1 is totally in accord with the sudden stops lately analysed by Calvo and others; and the varied experiences reveal how Latin America countries managed sovereign debts and resolved critical situations in their relations with the creditor advanced nations, as the following vignettes illustrate.

\subsection{Vignettes: sovereign borrowing episodes in Latin American economic history}

\subsubsection{The characteristics of sovereign bonds during the 1820-1930 period}

In the $19^{\text {th }}$ century, sovereign bonds typically had a very long maturity. They averaged more than 20 years while in the current globalisation of the 1990s and 2000s the issue of Eurobonds by emerging market sovereigns was at maximum maturities of 7-10 years. Some of the contemporary bonds may have had clauses of semi-automatic renewal, but we have still not observed anything like the 25-year bonds that were typically seen in the 1820s-1930s epoch. Also, in particular, the 1870-1913 period witnessed a situation in which early redemption clauses were the norm in the structuring of the public debt issues (the so-called «lottery clause», allowing partial repayment and conversion). This tells us that the international capital markets of the $19^{\text {th }}$ century (notably, the London Market) took a «friendly» approach towards debtor countries, allowing them to refinance and swap long-term debt instruments for comparable instruments at lower interest or coupon rates to exploit favourable liquidity conditions (Mauro et al. 2006).

As Bordo and Meissner (2005) have shown, most of the sovereign bonds floated by Latin American countries in the period were denominated in foreign currency or in terms of gold (or else had "gold clauses»). The limitation for an emerging country to issue a bond only in a hard or key currency was referred by Eichengreen and Hausmann (1999) as «original sin» and they viewed this as a symptom of extreme fragility that might explain the recurrence of interruptions in the original contractual debt obligations of the emerging market countries. 
FIGURE 6

ORIGINAL SIN

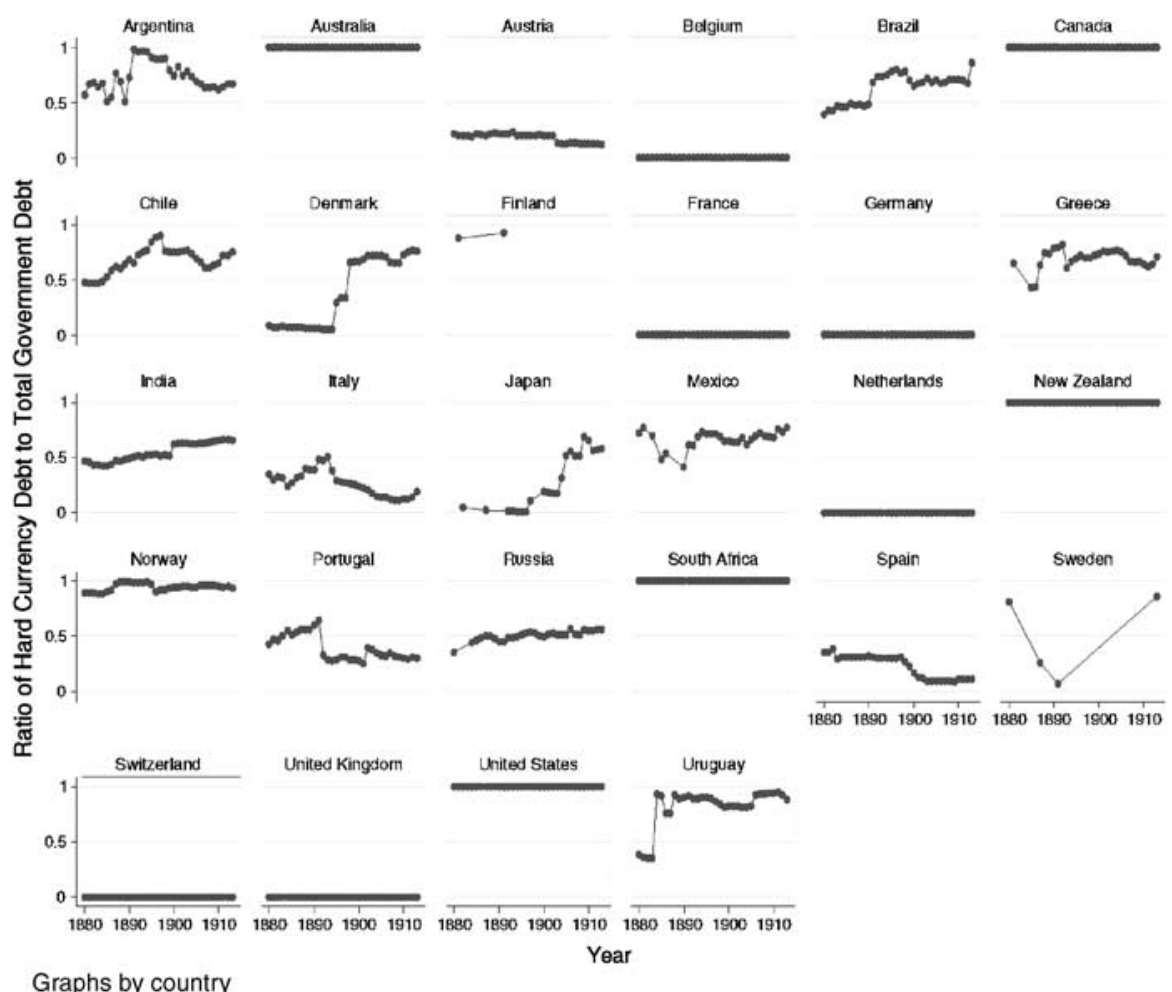

Source: Bordo and Meissner (2005).

Here, the linkages between monetary regimes, public finances, the level of economic activity, and the sovereign debt issued in foreign currency provides important insights that help explain recurrent problems in the management of the sovereign debt in Latin America countries?.

Owing to the acute credibility problems posed by the conduct of volatile monetary and fiscal policies, the Latin America countries also issued domestic debt with gold clauses. This is shown in Figure 6 taken from Bordo and Meissner (2005), we can see that two very big Latin American countries, Brazil and Argentina, consistently issued public debt by resorting to gold clauses or hard currency denominations.

9 On the Baring Crash of 1891 see Eichengreen (1999), della Paolera and Taylor (2001), Ferns (1992), Mitchener and Weidenmier (2008), Flores (2011). 
Finally a notable difference with today's international markets was that in many debt issues export revenues and tax revenues were earmarked as collateral to guarantee the servicing of the debt. In other words, it seems that some public bonds had explicit "seniority» over the same type of bonds issued by the same national political entity. Clauses linking different bonds - to prevent selective default - were not a central feature as they are in the present day international bond market.

\subsubsection{The cost of capital for a small independent nation: moral hazard and collusion among lenders and borrowers or the price to pay for the reputation of a newcomer?}

It is well known - notwithstanding the frictions and productivity differences underlying the Lucas paradox - that when the yield of available investments in the core countries drops, the international capital market has a strong tendency to funnel liquidity to more risky prospects in the periphery. This is evident today, but was just as true in the 1820s, 1870s and 1880s. Hence, the possibility of "overborrowing» arises when extremely high liquidity in international capital markets becomes an equilibrium possibility. An instance of «irrational exuberance» in the case of some of the riskier speculations in the wave of the 1820 s cannot be totally ruled out. It is implicit in the arguments of Flandreau and Flores (2009), and the following example illustrates.

A basic guiding principle can be set forth: potential lemons behave always like «seasoned» public bonds in good times - they just become junk bonds in bad times. The example of the $1824 £ 1$ million so-called "Baring loan» to the Province of Buenos Aires is a very interesting case that illuminates the behaviour of the various actors involved in a sovereign debt placement. As Peters (1934) explains, the loan was placed with Baring Brothers at 70 per cent. Barings then deducted 13 per cent of the par amount $(£ 130,000)$ so the loan yielded the Province of Buenos Aires a mere $£ 570,000$. Then the bonds were placed in the London market at 85 per cent of par, yielding to Baring Brothers a spread of 15 per cent, and a further $£ 150,000$ profit. With total profits of $£ 280,000$ on a loan of $£ 570,000$, the merchant house achieved a return of 49 per cent! This is one of the many instances noted by Fodor (2002, p. 35): he argues that data usually used for the Latin American loans cannot be accepted at face value and should be treated with many caveats. As far as the loans are concerned, perhaps there was no boom at all. While it is true that as market makers and subscribers, the merchant house had their reputation at stake, the initial phases of outburst of financial liquidity in the London market were exploited to the full by the same houses as well as by the policymakers in the recipient countries ${ }^{10}$.

10 As stated by Duncan (1983). 
FIGURE 7

REPUTATION: FIRST AND SECOND WAVE SPREADS

(a)

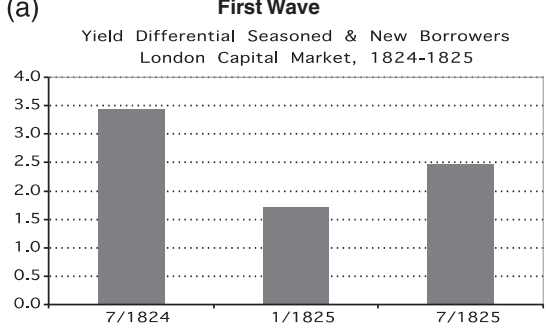

(b)

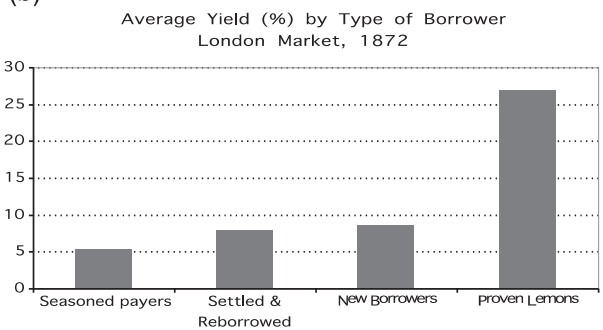

Source: Tomz (2001).

While the net proceeds to the recipient were very low in this first experiment of the Province of Buenos Aires, and indeed very profitable for the merchant houses, the gross yield to maturity of the bond approached 7 per cent, equivalent to a 4.5 per cent spread over the British consol. The «risk premium» or spread is traditionally viewed as the "price of access» to capital markets for emerging market borrowers and is in accord with Tomz (2007) who argues that it is not the particularities of the international capital market that characterise the interactive behaviour of investors and borrowers but rather the formation of reputation ${ }^{11}$. And reputations form in Bayesian way: creditors update the debtor's creditworthiness based on performance. Tomz considers two periods: the first wave (1820s) and the second wave (1870s). Then he identifies the differential premium between seasoned borrowers and new entries; in the second wave he also distinguishes between the good, the bad and the worse: that is, the payers, the resettlers and the defaulters.

As we can see from Figure 7, in the first wave, as in the example of Argentina given above, the Latin American economies were new borrowers par excellence and spreads were around 350 basis points. In the second wave of the 1870s, the market attached «reasonable» prices to the seasoned players, the new borrowers and the proven lemons or junk bonds (the latter having an average yield of 2,700 basis points).

The fall in yields from the 1820 s to the 1870 s marked an important development in the region's access to global markets. The high cost of capital in the first wave might have been associated with the building-up of reputation for the early borrowers, but, in addition, genuine asymmetric information problems were surely quite acute during the 1820-1870 period which would also drive up the required yield on a sovereign bond.

11 Basically his argument is that, even if outrageous, those large investment banking lump-sum fees are infra-marginal and can not characterise the dynamics of the sovereign debt market. 
FIGURE 8

LONDON LATIN AMERICAN BOND INDEX FOR THE FIRST WAVE

Latin American Bond Market in the 1820s

Composite Index*

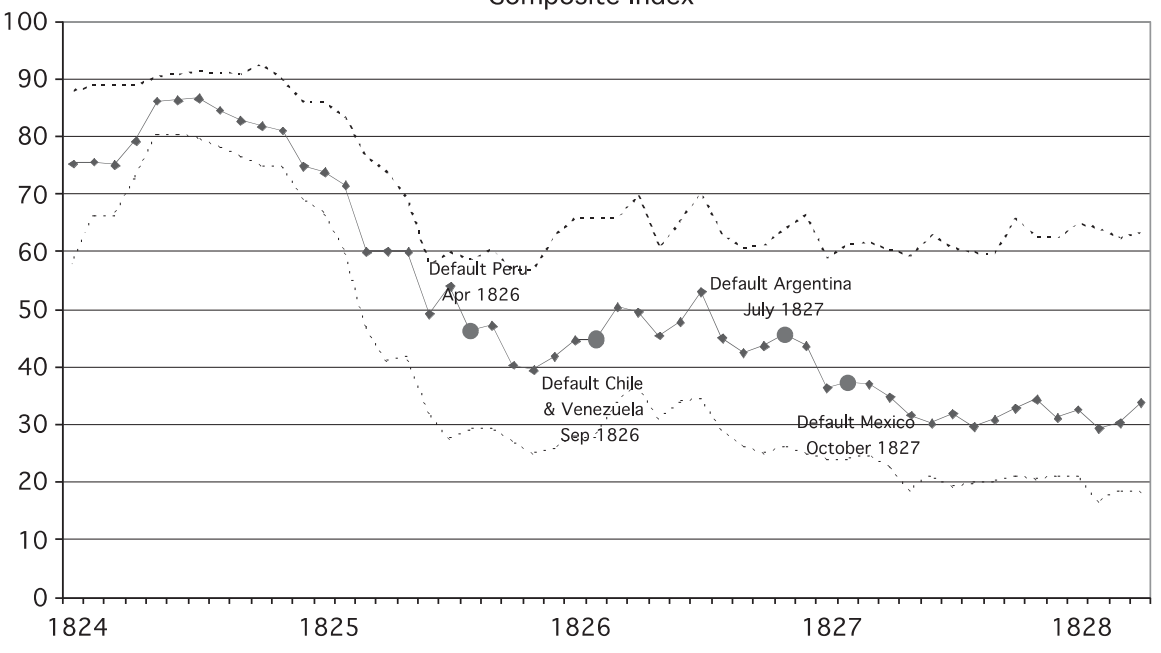

(*) See notes for details.

Source: See text.

\subsubsection{Availability of information and the importance of news}

Paucity of information was a major issue, especially until the second wave in the 1870s. In the 1820s there were in London several very important newspapers that compiled quite sophisticated data: on bond pricing and volumes traded, and also quotes on the political economy events of different countries. The Colonist, Common Sense, The Times and Course of Exchange followed closely the Latin American debt during the first phase on a daily basis until the generalised defaults of 1826-1827. From the information we could gather from the six years 1822-1828 were data on a good portion of the sovereign bonds outstanding, allowing us to construct a Latin American bond composite index that is quite comparable with the current EMBI index, as seen in Figure $8^{12}$.

12 We should not however underestimate the availability of internal information as Fodor (2002, p. 29) states: «There was also excellent private information circulating in Buenos Aires.... It strongly suggests that there were a few people in Buenos Aires that were extremely well informed of what was going on in London behind the scenes; they had much better inside information than that available to the average London investor». 
During the second wave, however, the availability of news was much more fluid. Information on macro variables such as outstanding debt per nation, trade flows, fiscal positions, population, railway construction as a proxy for investment, prices and quotations of sovereign bonds were readily available from additional sources such as Investor's Monthly Manual, The Economist, the Palmer's Index and from the Annual Reports of the Corporation of Foreign Bondholders that was created in the mid 1860s as an association of British investors holding bonds issued by the emerging economies.

Whether the availability of this information, plus the Consular Reports being drafted by the different Creditor Nations, meant a better understanding of the political economy realities of the Latin American countries is, we think, debatable. In the case of Argentina, Peters (1934) noted that:

A federal union was again formed in 1861, without definitely solving many of the controversial issues between Buenos Aires and the other provinces....the lack of knowledge of and confidence in the Argentine Republic, as distinct from Buenos Aires, led to the failure of the attempt [to float a national bond in 1866]...The Buenos Aires bonds remained about ten points above a national issue, indicating that the investors feared a possible dissolution of the union, and the possible repudiation of the debt by the province. (Peters 1934, p. 24)

He then shows clearly that the messy arrangements of fiscal federalism gave rise to asymmetric information for foreign investors, coordination problems at the national level, moral hazard and free riding. These problems have always been present and have made it very difficult to achieve a full understanding of the presence of different political subunits as major actors in the sphere of fiscal policy and debt management. These problems played a huge role in the Baring crash of 1891 and, again, in the Argentine crash of 2001 (della Paolera and Taylor 2003).

\subsubsection{Public debt and the degree of openness and the direction of international trade}

In a seminal paper Tomz (2001) analyses whether it is the threat of punishment or rather the desire to preserve reputation that prompts debtor countries to repay. Tomz states that traditionally, it has been argued that potential trade threats have compelled countries to honour their debts. Creditors could use a variety of threats to persuade debtors to pay, such as seizure of foreign assets, denial of short-term credit, or trade embargoes.

One by one, the author rejects the arguments based on punishment. In this work, he builds a case study based on the Argentine experience during the 1930s when the country was almost the sole Latin American country still 
honouring its debt service payments. He notes that there was no correlation between commercial dependence and debt repayment. Given that the United Kingdom was then Argentina's main trade partner, the traditional debt-trade argument implies that the country should prioritise payment to the United Kingdom. However, in the 1930s debt issued in the United States represented about 60 per cent of the total Argentine sovereign debt, and the debt in British pounds a mere 37 per cent. Yet Argentina respected full service payments on both accounts even when the U.S.-based debt was more expensive than the United Kingdom one.

At another level, in terms of political economy, the argument goes that should the trade-debt link hold, this would imply a consistent lobby by exporters against default. Yet Tomz finds that this is not exactly what happened in Argentine public debate. Rather, key legislators from cattle raising districts in the most important export-oriented provinces of Buenos Aires and Santa Fe, actually endorsed default. Finally, he concludes that even politicians claimed that reputation was the main reason to maintain debt service payments, apparently displaying some kind of far-sighted vision of the country's future (Tomz 2001, pp. 19-20).

\section{A SNAPSHOT OF SOVEREIGN DEBT MARKET DISRUPTIONS}

The above vignettes illustrate the many «imperfections» of the sovereign debt institutional context. Consequently, an important question arises about the manifestation and resolution of sovereign debt crises. Absent a strong international legal and contractual context that could enforce the promises of the young nations to honour their debts, what was the Latin American experience regarding the strategic behaviour of borrowers and lenders? We identify four major lessons in the historical record:

1. Outright repudiation or refinancing? - In the wave of the 1820 s, the main nations of Brazil (subject to the caveat noted earlier), Chile, Mexico, Peru, Gran Colombia, Federation of Central America and the Province of Buenos Aires (which seceded in the 1820s from the Argentine Confederation) all defaulted between 1826 and 1828. They had issued their sovereign bonds in the early 1820s, some tried to renegotiate but, with the exception of Brazil's brief moratorium, most of them could only restructure their situation by the 1850 s. The situation of most of them, except for the Mexican and Venezuelan cases, were regularised no later than the 1870s, with arrangements that capitalised interest and amortisation arrears. Although repayment was often very delayed, in this first wave there were no cases of outright repudiation.

In between the two waves, for the period 1850-1873, the approximate total of outstanding foreign loans to Latin America was $£ 140$ million — but 
TABLE 5

FOREIGN LOANS TO LATIN AMERICAN GOVERNMENTS, 1850-1873

\begin{tabular}{|c|c|c|c|c|c|}
\hline \multirow{2}{*}{\begin{tabular}{|l} 
\\
Country
\end{tabular}} & \multirow[b]{2}{*}{$\begin{array}{l}\text { Total no. } \\
\text { of loans }\end{array}$} & \multirow[b]{2}{*}{$\begin{array}{c}\text { Nominal value } \\
\text { (thousands of pounds) }\end{array}$} & \multicolumn{3}{|c|}{ Purpose (\%) } \\
\hline & & & Military & $\begin{array}{l}\text { Public } \\
\text { works }\end{array}$ & Refinance \\
\hline Argentina & 7 & 13,488 & 20 & 68 & 12 \\
\hline Bolivia & 1 & 1,700 & & 100 & 0 \\
\hline Brazil & 8 & 23,467 & 30 & 13 & 57 \\
\hline Chile & 7 & 8,502 & 37 & 51 & 12 \\
\hline Colombia & 2 & 2,200 & & 9 & 91 \\
\hline Costa Ria & 3 & 3,400 & & 100 & 0 \\
\hline Ecuador & 1 & 1,824 & & & 100 \\
\hline Guatemala & 2 & 650 & & 77 & 23 \\
\hline Haiti & 1 & 1,458 & & & 100 \\
\hline Honduras & 4 & 5,590 & & 98 & 2 \\
\hline Mexcio & 2 & 16,960 & 70 & & 30 \\
\hline Paraguay & 2 & 3,000 & & 80 & 20 \\
\hline Peru & 7 & 51,840 & 10 & 45 & 45 \\
\hline Santo Domingo & 1 & 757 & & 100 & 0 \\
\hline Uruguay & 1 & 3,500 & & & 100 \\
\hline Venezuela & 2 & 2,500 & & 30 & 70 \\
\hline \multicolumn{6}{|c|}{ Combined subtotals by subperiods } \\
\hline $1850-1859$ & 9 & 10,862 & & 32 & 68 \\
\hline $1860-1869$ & 20 & 56,705 & 41 & 12 & 47 \\
\hline $1870-1875$ & 22 & 73,270 & & 60 & 40 \\
\hline
\end{tabular}

Source: Marichal (1989, p. 80).

45 per cent of this stock was simply devoted to refinancing the defaults of the 1820s, as shown in Table 5. Later, after the crisis of 1873, which saw a massive fall in the price of commodities, eight Latin American countries defaulted as shown in Table 6, but most of them restructured in the decade of the 1880s with the exception of Honduras, which was in a perennial situation of default and was one of the few cases where the gunboat policy was applied in 1905-1907.

The case of Mexico deserves special attention here. It had the most extended period of default running from 1828 through 1888. By 18271828 Mexico stopped coupon payments on the bonds and in spite of successive attempts with successive Mexican governments, it was not 
TABLE 6

DEFAULTS AND SETTLEMENTS OF LATIN AMERICAN LOAN FOLLOWING THE CRISIS OF 1873

\begin{tabular}{|c|c|c|c|c|c|}
\hline $\begin{array}{l}\text { Government } \\
\text { defaulting }\end{array}$ & $\begin{array}{l}\text { Interest } \\
\text { rate }(\%)\end{array}$ & $\begin{array}{c}\text { Original } \\
\text { date of issue } \\
\text { of loans }\end{array}$ & $\begin{array}{c}\text { Nominal value } \\
\text { of unredeemed } \\
\text { principal }\end{array}$ & $\begin{array}{l}\text { Date of } \\
\text { default }\end{array}$ & Settlement \\
\hline Bolivia & 6 & 1872 & 1,654 & $1 / 1 / 1875$ & 1880 \\
\hline \multirow[t]{2}{*}{ Costa Rica } & 6 & 1871 & 940 & $1 / 11 / 1874$ & 1885 \\
\hline & 7 & 1872 & 2,362 & $1 / 4 / 1874$ & 1885 \\
\hline \multirow[t]{2}{*}{ Guatemala } & 5 & 1856 & 73 & $1 / 2 / 1875$ & $1882 / 1887$ \\
\hline & 6 & 1869 & 469 & $1 / 4 / 1875$ & $1882 / 1887$ \\
\hline \multirow{4}{*}{ Honduras } & 5 & 1856 & 79 & $1 / 4 / 1873$ & \multirow{4}{*}{$\begin{array}{l}\text { Still in default } \\
\text { by turn of the } \\
\text { century }\end{array}$} \\
\hline & 10 & 1867 & 901 & $1 / 1 / 1873$ & \\
\hline & 7 & 1869 & 2,177 & $1 / 3 / 1873$ & \\
\hline & 10 & 1870 & 2,243 & $1 / 1 / 1873$ & \\
\hline \multirow[t]{2}{*}{ Paraguay } & 8 & 1871 & 957 & $15 / 6 / 1874$ & 1885 \\
\hline & 8 & 1872 & 548 & $1 / 7 / 1874$ & 1885 \\
\hline \multirow[t]{3}{*}{ Peru } & 5 & 1869 & 265 & $1 / 1 / 1876$ & 1890 \\
\hline & 6 & 1870 & 11,142 & $1 / 1 / 1876$ & 1890 \\
\hline & 5 & 1872 & 21,547 & $1 / 1 / 1876$ & 1890 \\
\hline Santo Domingo & 6 & 1869 & 714 & $1 / 1 / 1873$ & 1888 \\
\hline Uruguay & 6 & 1871 & 3,165 & $1 / 8 / 1876$ & 1879 \\
\hline
\end{tabular}

Source: Marichal (1989, p. 120).

until 1888 with President Porfirio Díaz that the country worked out a complete scheme of financial readjustment to settle all early foreign loans. Before settling, virtually everything was attempted to regain access to capital markets, even an unusual debt-for-land swap offered to British bondholders. Finally in 1888, an amount equivalent to 12.2 million pounds was restructured and the haircut taken by the investors was estimated at 81 per cent ${ }^{13}$.

In the case of Peru, after the guano boom evaporated, the scheme to restructure the debt was a debt-for-concessions swap (the Grace Contract)

13 Preliminary estimations done by Kaminsky and Vega-García (2012), in which the haircut is defined as the percentage difference between the net present value of the old instruments and the new instruments negotiated; a high loss incurred by the investors via the haircut means a high degree of debt relief. 
for which the agreement meant the cancellation of all the foreign debts (principal and interest) in exchange for guano, concession of the whole national railways system for 66 years, and concessions of land (Vizcarra 2009; Kaminsky and Vega-García 2012). Hence, we can see that most countries were eager, and have used even heterodox mechanisms, to try to restructure their debts and resume service when they could take advantage of renewed liquidity in global capital markets.

2. A case of early default, resumption and restructuring - The Baring loan of 1822 to the Province of Buenos Aires is an interesting example of a situation where a default is a direct consequence of political economy events - in this case, the ongoing war with Brazil from 1825 until 1828 , which had a drastic consequences on internal monetary and fiscal institutions. Buenos Aires tried to maintain service on the London loan until 1827, in spite of a depreciation of the domestic paper currency of 220 per cent in the 1825-1827 period (Bordo and Végh 2002). In early January 1828 , the Times stated: «the dividends... will not be paid. That government (Buenos Aires) is unable to ship specie due to a blockade, and exchange was so unfavorable, that had the alternative of remitting bills been resorted to the government would have had to raise four dollars for everyone paid to the English creditor. But the war is wasting the resources of the country... They rely on another British loan, which they will never get» (Peters 1934, p. 18). What was then the behaviour of Juan Manual de Rosas, the Governor who ruled the Province from 1830 to 1852? Did he resume payments or did he entertain a strategy of partial repayments?

While Rosas took a unilateral position of default, he always maintained a position to resume payments. In 1842, interestingly enough, he offered a debt for land swap by offering the Malvinas Islands to Barings as a partial settlement, an offer that was rejected. In 1844 , he started to pay a partial monthly installment until a definitive settlement could take place. The government that succeeded Rosas and which reunited the province of Buenos Aires with the Argentine Confederation - proposed a consensual restructuring to Barings and initially doubled the monthly installment accepted by Rosas. In 1857, Argentina assumed and consolidated the full principal and the capitalisation of interest arrears along the lines of a previous Chilean restructuring in 1842. The Argentina restructuring of 1857 implied the issue of a new bond amounting to $£ 1,641,000$ to cover exactly for the arrears of interest on the outstanding $£ 970,000$ debt. Principal remained at par and there was a 2-year grace period for debt service. However, coupons were lowered from the original 6 per cent to just 3 per cent per annum.

Interestingly enough, both in the cases of Chile (a span of 18 years of outright default) and Argentina (a period of 16 years of outright 
TABLE 7

FOREIGN LOANS OF FIVE LATIN AMERICAN STATES, 1880-1890

\begin{tabular}{|l|c|c|}
\hline Country & No. of loans & Nominal value (thousands of pounds) \\
\hline Argentina & 50 & 77,985 \\
Brazil & 8 & 38,914 \\
Chile & 4 & 9,525 \\
Mexico & 5 & 21,850 \\
Uruguay & 4 & 18,782 \\
\hline
\end{tabular}

Note: These five states received close to $90 \%$ of the total Latin American foreign loans in this decade.

default and 13 years of a unilateral partial repayment scheme), the debt restructurings did not include any new money schemes. While in both cases, the principal amount in nominal values was maintained, because Chile resumed payments much earlier than Argentina, and because the Argentina coupon rate was cut in half, the Chilean investors suffered a considerably lower haircut: an estimated 44 per cent vs. an estimated 73 per cent for the Argentine case (Kaminsky and Vega-García 2012; Table 4).

3. Early modern bail-outs in sovereign debt episodes after the boom of the 1880s: a bad 1891 Funding Loan Agreement — In the period 1880s1890s Argentina alone was the recipient of 30 per cent of the total Latin American Foreign loans followed distantly by Brazil with 14 per cent of total foreign loans inflows to Latin America, as shown in Table 7. It is no surprise, then, that when Argentina started to reveal by the end of 1890 that it would have problems servicing its foreign debt, a panic arose in London and means were sought to avoid a contagion in the event of an Argentine default.

This event became famously known as the Baring Crash of 18901891. To avoid an all across the board default by Argentina, the Bank of England coordinated a rescue operation in January 1891 that involved a syndicate of merchant banks providing a «stand-by» loan of $£ 15$ million, a «6 per cent funding loan», to cover the full service of the external debt over three years for the Argentine Republic Bonds. Also, this arrangement known as the «de la Plaza-Bank of England» agreement included very harsh and contractionary conditionality measures. Yet, in spite of the stabilisation reform efforts, the package failed in 1892 to bring in a sustainable inter-temporal path of the debt service and principal payments for Argentina. The real yield at which the funding loan was floated was 16 per cent at a time of recession when the debt-output ratio rose from 72 per cent to 91 per cent. (Curiously enough, the conditions closely match the Argentina MegaSwap of 
May/June 2001 that was also effected at a yield rate of 16 per cent while the rate of growth of the economy was -2 per cent.) In fact, the burden of the debt increased for the recipient country, and the estimated haircut was of about -9 per cent, which meant that the underwriters would «expect» an even bigger transfer of resources from Argentina.

This also points to an alternative and quite different explanation for the Baring crash built on the microeconomic market structure involving the lenders to the country. Flores (2011) in a compelling paper argues that this potential explanation is not a surprising one if one addresses the microeconomic structure of the lending process to Argentina. In this view the overborrowing of Argentina occurs exactly in the period (1886-1889) of fiscal and macroeconomic deterioration, which gives support to his view that the underwriting market structure could worsen the overborrowing or «irrational exuberance» phenomena. That is to say, the Baring's branding was in some way «cannibalized» by the entry of less reputed financial houses. Curiously enough, to clean up this mess, a debt forgiveness package was proposed by J. J. Romero in 1893 to a Committee of Creditors headed by the House of Rothschild, the most reliable underwriter in the sovereign lending business, leading to a successful resolution (della Paolera and Taylor 2001, pp. 106-117).

Argentina's so-called Romero agreement of 1893 stated that, between 1893 and 1898 the national government would pay half the level of original debt service recognised in the de la Plaza-Bank of England agreement, then from 1898 onwards it would pay the full level of debt service, and finally from 1901 the government would begin to amortise principal on the National Sovereign Bonds. Therefore, the Argentine Republic Bonds were never «technically» in default, but they avoided default only by two sequential restructuring attempts. It is important to notice here that the Provincial and Municipal bonds were in default since 1891 and that the federal government was eventually to nationalise those obligations as late as 1898. Though foreign direct investment was not halted completely, Argentina grew slowly as an austere fiscal and monetary regime was imposed until they rejoined the gold standard in 1899; the government could only float new money bonds (i.e., not rollovers/refinancings) again in 1901 so, while foreign direct investment in the private sector gradually recovered, the public sector was in virtually in financial autarky for almost a decade.

\section{CONCLUSION}

Latin America may always be the greatest historical laboratory for the analysis and understanding of sovereign debt and default. Its long postindependence history, its early embrace of external debt, and its persistent political and macroeconomic volatility have meant that for 200 years the 
countries of the region have confronted hard choices about the optimal path of debt, repayments and restructurings.

Seeking an analytic narrative, this paper takes the region's $19^{\text {th }}$-century history as a backdrop and aims to integrate the well-known narrative contours of this sovereign debt and default experience with contemporary research in economic theory and quantitative evidence from econometric analysis. At a macro level, the natural neoclassical «downhill» flow of capital to the region generally went in the expected direction on average. But the tendency of these flows to clump in great surges, followed by retrenchments and often sovereign defaults, commands further explanations. In many cases economic fundamentals mattered (e.g., the rise and fall of guano prospects) but political conditions played a large role (especially before 1860, with Brazil being the exception that proved the rule). Contagion is apparent in some cases, as when the Baring crisis spread far and wide beyond the River Plate economies. And at a microeconomic level, the effects of imperfect information and market structure, and hence the role of intermediaries, cannot be discounted. As early as the 1820 s bad information was a vehicle for simple fraud but even decades later asymmetries remained.

These findings have echoes in the emerging world at present, as in Latin America (and even in the so-called advanced countries, taking into account Eurozone fiscal and banking union tensions). As in 1800, the world lacks a sovereign bankruptcy procedure, and may for some time, so the occurrence and resolution of sovereign default problems remain: witness the Argentine 2002 default still as it still wends its way through U.S. courts. But absent such fundamental changes, history warns that next time is unlikely to be different, and external debt flows of the future may continue to be at risk of the exuberance, collapse, default and resolution problems of old. If that is the road ahead, then Latin America will continue to be a useful reference map.

\section{REFERENCES}

Accominotti, O.; Flandreau, M., and RezziK, R. (2011): «The Spread of Empire: Clio and the Measurement of Colonial Borrowing Costs». Economic History Review 64 (2), pp. 385-407.

Acemoglu, D.; Johnson, S., and Robinson, J. A. (2001): "The Colonial Origins of Comparative Development: An Empirical Investigation». American Economic Review 91 (5), pp. 1369-1401.

Alfaro, L.; Kalemli-Ozcan, S., and Volosovych, V. (2005): Capital Flows in a Globalized World: The Role of Policies and Institutions. NBER Working Paper 11696.

Amador, M. (2004): A Political Model of Sovereign Debt Repayment. Meeting Papers 762, Society for Economic Dynamics.

BARRo, R. J. (1989): «The Ricardian Approach to Budget Deficits». Journal of Economic Perspectives 3 (2), pp. 37-54.

Bordo, M. D., and Kydland, F. E. (1995): «The Gold Standard As a Rule: An Essay in Exploration». Explorations in Economic History 32 (4), pp. 423-464. 
Bordo, M. D., and, Meissner, C. M. (2005): The Role of Foreign Currency Debt in Financial Crises: 1880-1913 vs. 1972-1997. NBER Working Paper 11897.

Bordo, M. D., and Rockoff, H. (1996): «The Gold Standard as a "Good Housekeeping Seal of Approval»». Journal of Economic History 56 (2), pp. 389-428.

Bordo, M. D., and VÉGH, C. A. (2002): "What if Alexander Hamilton had been Argentinean? A Comparison of the Early Monetary Experiences of Argentina and the United States». Journal of Monetary Economics 49 (3), pp. 459-494.

Bulow, J., and Rogoff, K. (1989): «Sovereign Debt: Is to Forgive to Forget?». American Economic Review 79 (1), pp. 43-50.

Calvo, G. (1998): "Capital Flows and Capital-Market Crises: The Simple Economics of Sudden Stops». Journal of Applied Economics 1 (1), pp. 35-54.

Cardoso, E. A., and Dornbusch, R. (1989): «Brazilian Debt Crises: Past and Present», in B. J. Eichengreen, and P. H. Lindert (eds), The International Debt Crisis in Historical Perspective. Cambridge, MA: MIT Press, pp. 106-139.

Cole, H. L., and Kenoe, P. J. (1996): Reputation Spillover Across Relationships: Reviving Reputation Models of Debt. Federal Reserve Bank of Minneapolis Staff Report 209.

Davis, L. E. (1965): «The Investment Market, 1870-1914: The Evolution of a National Market». Journal of Economic History 25 (3), pp. 355-399.

Davis, L. E., and Gallman, R. E. (2001): Evolving Financial Markets and International Capital Flows: Britain, The Americas, and Australia, 1865-1914. Japan-U.S. Center Sanwa Monographs on International Financial Markets. Cambridge: Cambridge University Press.

Davis, L. E., and Huttenback, R. A. (1988): Mammon and the Pursuit of Empire: The Economics of British Imperialism. Cambridge: Cambridge University Press.

de Paiva Abreu, M. (2006): «Brazil as a Debtor, 1824-1931». Economic History Review 59 (4), pp. 765-787.

della Paolera, G., and Taylor, A. M. (2001): «Straining at the Anchor: The Argentine Currency Board and the Search for Macroeconomic Stability, 1880-1935». NBER Series on Long-Term Factors in Economic Growth. Chicago: University of Chicago Press. della Paolera, G., and Taylor, A. M. (2003): «Gaucho Banking Redux». Economía 3 (2), pp. $1-42$.

DunCan, T. (1983): «La política fiscal durante el gobierno de Juárez Celman, 1886-1890: una audaz estrategia financiera internacional». Desarrollo Económico 23, pp. 11-34.

Easterly, W., and Levine, R. (2001): "What Have We Learned From a Decade of Empirical Research on Growth? It's Not Factor Accumulation: Stylized Facts and Growth Models». World Bank Economic Review 15 (2), pp. 177-219.

Eaton, J., and Gersovitz, M. (1981): «Debt with Potential Repudiation: Theoretical and Empirical Analysis». Review of Economic Studies 48 (2), pp. 289-309.

Eichengreen, B. (1999): «The Baring Crisis in a Mexican Mirror». International Political Science Review 20 (3, pp. 249-270.

Eichengreen, B., and Hausmann, R. (1999): «Exchange Rates and Financial Fragility», in New Challenges for Monetary Policy. Proceedings of the Jackson Hole Economic Policy Symposium, Jackson Hole, Wyo., August 26-28, 1999. Kansas City: Federal Reserve Bank of Kansas City, pp. 329-368.

FeIs, H. (1931): Europe: The World's Banker: 1870-1914. New Haven: Yale University Press.

Ferguson, N. (2001): The Cash Nexus: Money and Power in the Modern World, 1700-2000. New York: Basic Books.

Ferguson, N. (2003): Empire: How Britain Made the Modern World. London: Allen Lane. 
Ferguson, N., and Schularick, M. (2006): «The Empire Effect: The Determinants of Country Risk in the First Age of Globalization, 1880-1913». Journal of Economic History 66 (2), pp. 283-312.

Ferguson, N., and Schularick, M. (2012): «The «Thin Film of Gold»: Monetary Rules and Policy Credibility'». European Review of Economic History 16 (4), pp. 384-407.

Ferns, H. S. (1992): «The Baring Crisis Revisited». Journal of Latin American Studies 24 (2), pp. 241-273.

Fishlow, A. (1989): «Conditionality and Willingness to Pay: Some Parallels from the 1890s», in B. J. Eichengreen and P. H. Lindert (eds), The International Debt Crisis in Historical Perspective. Cambridge, MA: MIT Press, pp. 86-105.

Flandreau, M., and Zumer, F. (2004): The Making of Global Finance, 1880-1913. Paris: OECD.

Flandreau, M., and Flores, J. H. (2009): «Bonds and Brands: Foundations of Sovereign Debt Markets, 1820-1930». Journal of Economic History 69 (3), pp. 646-684.

Flores, J. H. (2011): "Information Asymmetries and Conflict of Interest During the Baring Crisis, 1880-1890». Financial History Review 18 (2), pp. 191-215.

Fodor, G. (2002): The Boom That Never Was? Latin American Loans in London. Universita degli Studi di Trento, Dipartimento di Economia, Discussion Paper 5.

Glaeser, E. L.; La Porta, R.; Lopez-de-Silanes, F., and Shleifer, A. (2004): «Do Institutions Cause Growth?». Journal of Economic Growth 9 (3), pp. 271-303.

Gurley, J. G., and Shaw, E. S. (1955): «Financial Aspects of Economic Development». American Economic Review 45, pp. 515-538.

HaBER, S. (1991): «Industrial Concentration and the Capital Markets: A Comparative Study of Brazil, Mexico, and the United States, 1830-1930». Journal of Economic History 51 (3), pp. 559-580.

Hall, R. E., and Jones, C. I. (1999): «Why Do Some Countries Produce So Much More Output Per Worker Than Others?». Quarterly Journal of Economics 114 (1), pp. 83-116.

Hanley, A. G. (2005): Native Capital: Financial Institutions and Economic Development in São Paulo, Brazil, 1850-1920. Stanford, CA: Stanford University Press.

Kaminsky, G., and Vega-García, P. (2012): Varieties of Sovereign Crises: Latin America, 1820-1931. George Washington University. Unpublished.

King, R. G., and Levine, R. (1993): «Finance and Growth: Schumpeter Might Be Right». Quarterly Journal of Economics 108 (3), pp. 717-737.

KLetzer, K. M., and Wright, B. D. (2000): «Sovereign Debt as Intertemporal Barter». American Economic Review 90 (3), pp. 621-639.

Lindert, P. H., and Morton, P. J. (1989): «How Sovereign Debt has Worked», in J. D. Sachs (ed.), Developing Country Debt and the World Economy. Chicago: University of Chicago Press.

LuCAS, R. E. JR (1990): «Why Doesn't Capital Flow From Rich to Poor Countries?». American Economic Review 80 (2), pp. 92-96.

Marichal, C. (1989): A Century of Debt Crises in Latin America: From Independence to the Great Depression, 1820-1930. Princeton, NJ: Princeton University Press.

Mauro, P.; Sussman, N., and Yafeh, Y. (2006): Emerging Markets and Financial Globalization: Sovereign Bond Spreads in 1870-1913 and Today. Oxford: Oxford University Press.

Meissner, C. M. (2005): «A New World Order: Explaining the International Diffusion of the Gold Standard, 1870-1913». Joumal of International Economics 66 (2), pp. 385-406.

Mitchener, K. J., and Weidenmier, M. (2005): «Empire, Public Goods, and the Roosevelt Corollary». Journal of Economic History 65 (3), pp. 658-692. 
Mitchener, K. J., and Weidenmier, M. (2008): «The Baring Crisis and the Great Latin American Meltdown of the 1890s». Journal of Economic History 68 (2), pp. 462-500.

North, D. C., and Thomas, R. P. (1973): The Rise of the Western World: A New Economic History. New York: Cambridge University Press.

Obstfeld, M., and TaYlor, A. M. (2003): «Sovereign Risk, Credibility, and the Gold Standard: 1870-1913 versus 1925-31». Economic Journal 113 (487), pp. 1-35.

OBstreld, M., and TAylor, A. M. (2004): Global Capital Markets: Integration, Crisis, and Growth. Japan-U.S. Center Sanwa Monographs on International Financial Markets Cambridge: Cambridge University Press.

Peters, H. E. (1934): The Foreign Debt of the Argentine Republic. Baltimore: Johns Hopkins Press.

Prados de la Escosura, L. (2005): Growth, Inequality, and Poverty In Latin America: Historical Evidence, Controlled Conjectures. Economics History and Institutions Working Papers wh054104, Universidad Carlos III, Departamento de Historia Económica e Instituciones.

Regalsky, A. (2002): Mercados, inversiones y élites. Las inversiones francesas en la argentina 1880-1914. Buenos Aires: EDUNTREF.

Reinhart, C. M., and Rogoff, K. S. (2004): «Serial Default and the «Paradox» of Rich-toPoor Capital Flows». American Economic Review 94 (2), pp. 53-58.

Reinhart, C. M.; Rogoff, K. S., and Savastano, M. A. (2003): «Debt Intolerance». Brookings Papers on Economic Activity 34 (1), pp. 1-74.

Reinhart, C. M., and Rogoff, K. (2009): This Time is Different: Eight Centuries of Financial Folly. Princeton, NJ: Princeton University Press.

RIPPY, J. F. (1959): British Investments in Latin America, 1822-1949: A Case Study in the Operations of Private Enterprise in Retarded Regions. Minneapolis: University of Minnesota Press.

Rose, A. K., and Spiegel, M. M. (2002): A Gravity Model of Sovereign Lending: Trade, Default and Credit. NBER Working Paper 9285.

Sachs, J. D.; Gallup, J. L., and Mellinger, A. (1998): Geography and Economic Development. NBER Working Paper 6849.

SACHS, J. D., and WARnER, A. M. (1995): «Economic Reform and the Process of Global Integration». Brookings Papers on Economic Activity 26 (1), pp. 1-118.

Schularick, M., and Steger, T. M. (2006): Does Financial Integration Spur Economic Growth? New Evidence from the First Era of Financial Globalization. Economics Working Paper 06/46, Institute of Economic Research, Swiss Federal Institute of Technology Zurich.

Schumpeter, J. [1911] (1934): The Theory of Economic Development. Cambridge, MA: Harvard University Press.

Stone, I. (1977): «British Direct and Portfolio Investment in Latin America Before 1914». Journal of Economic History 37 (3), pp. 690-722.

Stone, I. (1999): Global Export of Capital from Great Britain, 1865-1914: A Statistical Survey. New York: St. Martin's Press.

Suter, C. (1992): Debt Cycles In the World Economy: Foreign Loans and Debt Settlements: 1820-1990. Boulder, CO: Westview.

TAYLOR, A. M. (1992): «External Dependence, Demographic Burdens, and Argentine Economic Decline After the Belle Époque». Journal of Economic History 52 (4), pp. 907-936.

TAYLOR, A. M. (2005): «Foreign Capital in Latin America in the Nineteenth and Twentieth Centuries», in V. Bulmer-Thomas, J. H. Coatsworth, and R. Cortés Conde (eds), The Cambridge Economic History of Latin America: Volume 2, The Long Twentieth Century. Cambridge: Cambridge University Press, pp. 57-100. 
Taylor, A. M., and Williamson, J. G. (1994): «Capital Flows to the New World as an Intergenerational Transfer». Journal of Political Economy 102 (2), pp. 348-371.

Tomz, M. (2001): How Do Reputations Form? New and Seasoned Borrowers in International Capital Markets. Paper presented at the Annual Meetings of the American Political Science Association, San Francisco.

Tomz, M. (2007): Sovereign Debt and International Cooperation. Princeton, NJ: Princeton University Press.

Triner, G. D. (2000): Banking and Economic Development: Brazil, 1889-1930. New York: St. Martin's Press.

Twomey, M. J. (2000): A Century of Foreign Investment in the Third World. London: Routledge.

VizCARRA, C. (2009): «Guano, Credible Commitments, and Sovereign Debt Repayment in Nineteenth-Century Peru». Journal of Economic History 69 (2), pp. 358-387.

Wright, M. L. J. (2002): Reputations and Sovereign Debt. Stanford University. Photocopy. 